\title{
Alternative Strategies for Controlling Wireworms in Field Crops: A Review
}

\author{
Sylvain Poggi ${ }^{1} *$ (D) Ronan Le Cointe ${ }^{1}$, Jörn Lehmhus ${ }^{2}$, Manuel Plantegenest ${ }^{1}$ and Lorenzo Furlan ${ }^{3}$ (D) \\ 1 INRAE, Institute for Genetics, Environment and Plant Protection (IGEPP), Agrocampus Ouest, \\ Université de Rennes, 35650 Le Rheu, France; ronan.le-cointe@inrae.fr (R.L.C.); \\ Manuel.Plantegenest@agrocampus-ouest.fr (M.P.) \\ 2 Institute for Plant Protection in Field Crops and Grassland, Julius Kühn-Institute, \\ 38104 Braunschweig, Germany; joern.lehmhus@julius-kuehn.de \\ 3 Veneto Agricoltura, 35020 Legnaro, Italy; lorenzo.furlan@venetoagricoltura.org \\ * Correspondence: sylvain.poggi@inrae.fr
}

Citation: Poggi, S.; Le Cointe, R.;

Lehmhus, J.; Plantegenest, M.; Furlan,

L. Alternative Strategies for

Controlling Wireworms in Field

Crops: A Review. Agriculture 2021, 11,

436. https://doi.org/10.3390/

agriculture11050436

Academic Editor: Eric Blanchart

Received: 3 April 2021

Accepted: 7 May 2021

Published: 11 May 2021

Publisher's Note: MDPI stays neutral with regard to jurisdictional claims in published maps and institutional affiliations.

Copyright: (C) 2021 by the authors. Licensee MDPI, Basel, Switzerland. This article is an open access article distributed under the terms and conditions of the Creative Commons Attribution (CC BY) license (https:/ / creativecommons.org/licenses/by/ $4.0 /)$.

\begin{abstract}
Wireworms, the soil-dwelling larvae of click beetles (Coleoptera: Elateridae), comprise major pests of several crops worldwide, including maize and potatoes. The current trend towards the reduction in pesticides use has resulted in strong demand for alternative methods to control wireworm populations. This review provides a state-of-the-art of current theory and practice in order to develop new agroecological strategies. The first step should be to conduct a risk assessment based on the production context (e.g., crop, climate, soil characteristics, and landscape) and on adult and/or larval population monitoring. When damage risk appears significant, prophylactic practices can be applied to reduce wireworm abundance (e.g., low risk rotations, tilling, and irrigation). Additionally, curative methods based on natural enemies and on naturally derived insecticides are, respectively, under development or in practice in some countries. Alternatively, practices may target a reduction in crop damage instead of pest abundance through the adoption of selected cultural practices (e.g., resistant varieties, planting and harvesting time) or through the manipulation of wireworm behavior (e.g., companion plants). Practices can be combined in a global Integrated Pest Management (IPM) framework to provide the desired level of crop protection.
\end{abstract}

Keywords: click beetle; crop damage; integrated pest management; risk assessment; pest monitoring; biocontrol; landscape feature; habitat manipulation; companion plant; mutual fund

\section{Introduction}

Agriculture is facing major challenges, i.e., global change and societal pressure to preserve the environment. Climate change may progressively alter the spatial distribution of species or their life cycle (e.g., voltinism), raising new concerns about crop protection against pests and pathogens. Societal awareness of the deleterious effects of chemical pesticides and fertilizers for both environmental and human health has increased with the publication and dissemination of studies reporting dramatic declines in animal populations and biodiversity (regarding entomofauna, see for example [1-3]), with change being called for in the agricultural production system, notably toward more environmentally friendly crop-management practices. Such a demand sometimes spreads in the government bodies. In this respect, the European Union introduced Directive 128/2009/EC, which made the implementation of Integrated Pest Management (IPM) principles compulsory, as described by the European network ENDURE (www.endure-network.eu, accessed on 9th of May 2021), and progressively banned various chemical products for which undesirable effects had been evidenced (e.g., neonicotinoids for their severe impact on pollinators [4,5]). New threats to crops concomitantly with a reduced availability of pesticides have put farmers in a difficult situation, and calls have come for alternative strategies to control pests and diseases, both preventative and curative. 
The control of wireworms, the soil-dwelling larvae of click beetles (Coleoptera: Elateridae), is a remarkable illustration of this issue, and is the focus of this review. Wireworms, of which there are thousands of species but only a few harmful to agricultural crops, have been notorious as major pests worldwide for a long time. At the beginning of the 20th century, when chemicals were much less used, wireworms were considered the most harmful pests to arable crops [6]. Indeed, they can inflict severe economic damage on several major arable crops (e.g., potato, maize, and cereals) across Europe and North America [7], and the research effort into controlling these pests has risen considerably over the last few decades (Figure 1). Wireworms are extremely polyphagous pests and feed on nearly all cultivated (all cereals; all kinds of vegetables including onions, leek, and garlic; maize; potatoes; sweet potatoes; ornamentals, sugar beet and more) and wild plant species, including weeds. Additionally, most species relevant to agriculture are not only herbivorous but feed also on animal preys available in the soil (insect larvae and pupae or earthworms). Some crops are less susceptible to wireworm damage in terms of stand and yields because of agronomic characteristics (plant growth rate and density, tissues susceptibility, sowing date). This leads to the perception that some crops are specifically attacked while this is in general not the case. Elaterids exhibit a prolonged larval stage in the soil before pupation. Based on their life cycle, they fall into two groups: species overwintering as adults, and species not overwintering as adults [8]. The life cycles lasts $1-5$ years [6,9-12], with only the adult stage dwelling outside the soil: a few days for species non-overwintering at the adult stage, and several months for species overwintering at the adult stage. Incidentally, the spatial distribution of species is changing probably due to climate change (e.g., A. sordidus is becoming a major pest in parts of Germany [13]). Meanwhile, moratoriums imposed by many countries on neonicotinoid seed treatments, as well as restrictions and deregistration of several active substances, have fostered the search for alternative environmentally friendly solutions for wireworm pest control.

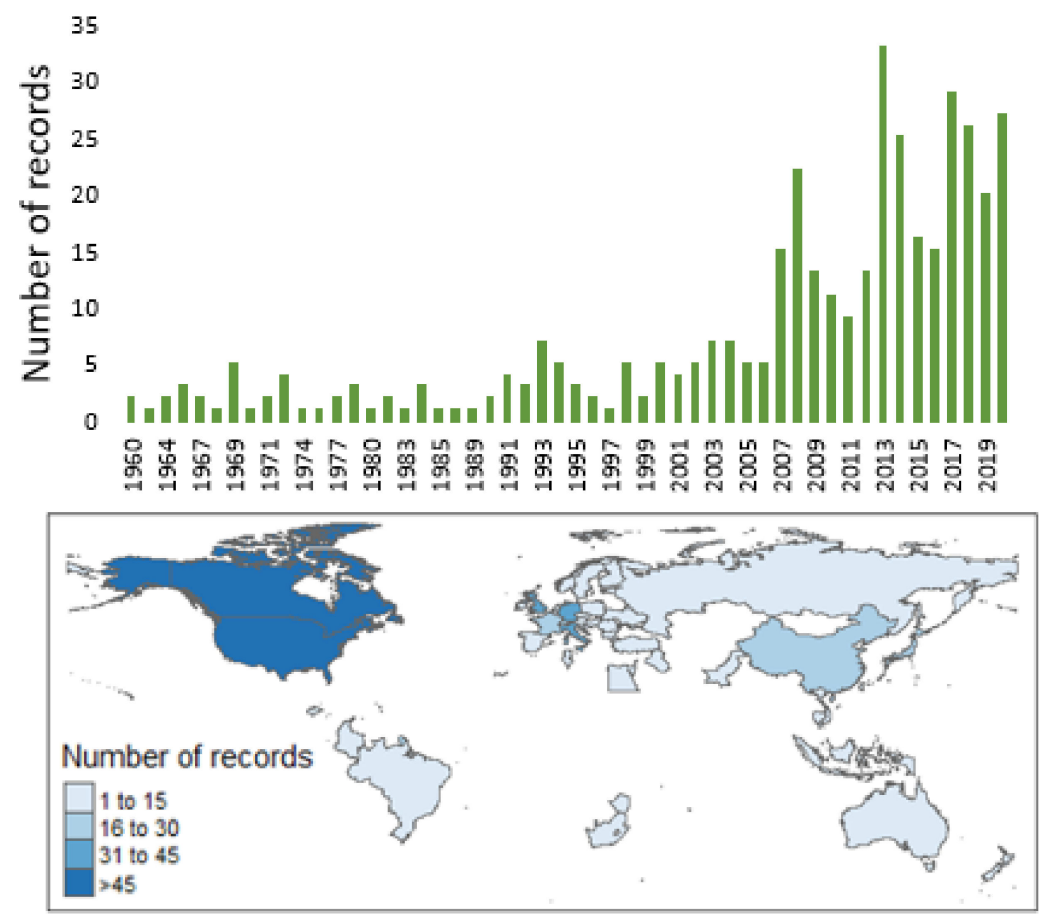

Figure 1. Number of articles published annually from 1960 to 2020 (barplot) and their distribution across countries (world map), according to the Web of Science request formulated on 30 March 2021 as follows: (wireworm* OR (click AND beetle*) OR agriotes) AND (IPM OR biocontrol OR control OR management OR regulation OR "risk assessment" OR “decision support" OR DSS). A total of 386 articles were published over the period under study, with a sharp rise around 2005. 
Damage inflicted on crops results from the interaction between wireworm field abundance and host susceptibility under abiotic constraints. Alternative crop-protection strategies to the systematic use of chemicals should target one or both of these two components in order to contain damage under the economic threshold. Achieving this requires an in-depth understanding of pest biology and ecology and of host plant phenology, as well as of the main processes at stake in their interactions. While the sensitive phenological stages of the host crop are often well-known, knowledge of the biology and ecology of wireworms is still incomplete. As an example, while the duration of the feeding phase varies according to larval instar $[9,10,14]$, the entire life cycle of some species still needs to be described (e.g., A. lineatus, A. sputator).

Strategies aiming at reducing wireworm densities below the economic threshold (when available) should integrate more than one practice with a partial impact and can be achieved through long-term management along the crop rotation and at different spatial scales. Preventive practices include applying crop rotations unfavorable to oviposition and wireworm survival, tilling when edaphic conditions are conducive to destroying soildwelling life stages, incorporating plants or extracts with biofumigant and allelochemical properties into soil, the use of natural enemies for pest control, and the manipulation in space and time of favorable areas (e.g., managing grassland regimes). Practices targeting the containment of crop damage below an economic threshold (limitation of harmfulness) despite substantial larval densities rely on identifying optimal planting and harvest conditions, protecting the sensitive crop with attractive companion plants, increasing seeding rates, and planting more tolerant cultivars. Reaching a satisfactory level of crop protection requires a combination of agronomic practices, thereby designing an Integrated Pest Management strategy (IPM) whose foundations are stated in Barzman et al. [15]. IPM faces the challenge of assessing which protection methods are compatible and how to set their combination so that the resulting crop protection has sufficient efficacy.

Our aim in this paper is to provide a comprehensive state-of-the-art of alternative wireworm management practices to insecticide use and suggest a holistic approach to exploiting them as IPM packages that include two or more alternative practices as replacements for insecticides. First, considering that any relevant management strategy requires accurate risk assessment, we address the question of risk assessment in terms of wireworm infestation or crop damage and of wireworm population monitoring. Indeed, a basic efficient alternative to the preventive use of insecticides can be doing nothing when risk is low or waiving the planting of a susceptible crop where and when the risk is high. Then, we present the main pesticide-free methods for controlling wireworms and elaborate on their putative combinations within an IPM framework. Finally, we outline a future research avenue that will lead to reduced use of insecticides for controlling wireworms in field crops.

\section{Risk Assessment}

Assessing the risk of wireworm infestation or crop damage is the first and most efficient alternative to the preventive use of insecticides, as it provides guidance on the selection of fields with low risk of economic damage. Risk assessment relies on the evaluation of factors that favor field infestation or crop damage and is a preventive tool. In its most advanced form, it consists of a decision-support system. It can also stem from the monitoring of pest populations, at different development stages, mainly at plot scale, and trigger the adoption of corrective tactics or the adaptation of preventive strategies.

\subsection{Evaluation of Risk Factors}

\subsubsection{Risk Factors}

Farmers' expertise, studies and reviews dealing with wireworm biology and ecology, and control methods highlight different categories of the factors that drive wireworm infestation and result in crop damage (Table 1). 
The feeding behavior of wireworms generally involves periods of inactivity in deep soil layers, mainly in summer or winter when soil environmental conditions are adverse. This inactivity alternates with foraging periods in autumn and spring when soil conditions become more favorable in the upper soil layers [9-11,16-18]. Climate, soil properties, and their interactions influence the vertical migration dynamics of wireworms, thereby influencing the damage they might cause to field crops.

As stated in the introduction, the multiannual biological life cycle of most wireworm species $[9-11,19,20]$ features a prolonged period spent as larvae in the soil before pupation. It outlines the prominent influence of soil characteristics on wireworm infestation and damage. Jung et al. [21] showed preferred ranges of soil moisture by wireworms in relation to four soil types and for different Agriotes species. Lefko et al. [22] outline the importance of soil moisture in wireworm survival and spatial distribution, suggesting that soil moisture could reveal areas where wireworms are more likely to occur and could direct scouting within a field. Furlan et al. [23] conducted a long-term survey on maize fields (1986-2014), concluding that organic-matter content was the strongest risk factor for economic damage. The risk of damage increased considerably when its value was greater than 5\%. Kozina et al. [24] reported that humus content (\%), together with the current crop being grown, was the best predictor of high Agriotes lineatus abundance. They also found that soil $\mathrm{pH}$ was a strong predictor for the abundance of A. obscurus and A. ustulatus. Based on a large-scale survey carried out in 336 maize fields over three years in France, Poggi et al. [25] concluded that soil characteristics had a prominent influence on wireworm damage risk, ranking them third after the presence of wireworms and climatic variables, with both $\mathrm{pH}$ and organic-matter content also being major factors. The effects of soil texture, drainage, and other factors can be found in the literature (see for example Furlan et al. [23]).

The frequency and intensity of wireworm damage varies across regions. Fields exhibiting high larval populations tend to be spatially clustered [26,27]. The distribution of adult click beetles in the landscape is patchy and can be stable for several consecutive years $[28,29]$. On a smaller scale, Salt and Hollick [30] confirmed farmers' observation that damage can appear in the same area of the field over several years. Taken together, these features suggest that regional and field characteristics, including agricultural practices and landscape context, are important factors in determining wireworm population (see Parker and Seeney [31]).

It is commonly stated that grasslands, as well as uncropped field margins and areas, provide the most favorable habitat for egg-laying and larval development [10,32], and may act as reservoirs from which larvae and click beetles disperse into adjacent crops [33,34]. Field history, plus landscape context through its effect on click beetle dispersal, may shape the pest abundance at the field scale.

Identifying which wireworm species are present (Figure 2) may be of importance, as wireworm damage is species dependent $[35,36]$. Several Agriotes species are the major contributors to wireworm damage in Europe, but species composition and co-occurrence with other wireworms vary, and other genera, such as Selatosomus, Hemicrepidius, and Athous, can also be very important locally [23,37-42]. In North America, several further genera, including Selatosomus (spp. formerly added to Ctenicera), Limonius, Conoderus, Melanotus, and Aeolus, are also economically important, as are native and introduced Agriotes [43-47]. In East Asia, Melanotus appear to be important, but there are also damaging species from other genera, e.g., Agriotes [48,49]. In a long-term study conducted in northeast Italy, Furlan [35] showed that damage symptoms, and thus crop damage, differed according to species. About the same damage level was observed for one larva of Agriotes brevis per trap, as for two larvae of $A$. sordidus or five larvae of $A$. ustulatus per trap. Feeding activity may vary significantly between species, thus calling for management strategies that should be tailored to their seasonal dynamics [50]. Similarly, click beetle species differ in their preferences for soil properties and climate characteristics [51]. When studying the effect of factors on risk damage, researchers may fail to spot an effect when priori species have not been identified. Saussure et al. [52] justified their failure to identify an effect of 
soil properties by the fact that they did not distinguish between the wireworm species present in the surveyed fields.

Eventually, agricultural practices alter the pest population and crop damage, thereby providing the components of putative prevention strategies (\$3). For example, when appropriately applied, tillage reduces populations of eggs and young larvae by damaging them mechanically. Furthermore, delaying the sowing date may help reduce damage by desynchronizing the period of wireworm presence in the upper soil layers and the period during which the field crop is sensitive to wireworm attacks.

Table 1. List of risk factors driving wireworm infestation and resulting in crop damage. Cited references provide examples of studies evaluating the risk factor, without any claim for exhaustiveness. A considerable effort would be required to achieve an overview of all situations in terms of species $\times$ crop $\times$ location.

\begin{tabular}{|c|c|c|c|}
\hline Risk Factor & $\begin{array}{l}\text { Potential for } \\
\text { Increasing } \\
\text { Damage Risk }\end{array}$ & Factor Effect & Reference \\
\hline \multicolumn{4}{|c|}{ Climate } \\
\hline Soil temperature & Medium-High & $\begin{array}{c}\uparrow \mathrm{T}^{\circ} \mathrm{C} \text { before seeding } \Rightarrow \downarrow \text { damage risk } \\
\text { and } \sim 12{ }^{\circ} \mathrm{C} \text { threshold (Agriotes spp. in maize) } \\
\uparrow \mathrm{T}{ }^{\circ} \mathrm{C} \Rightarrow \uparrow \text { total abundance of wireworm community } \\
\quad \text { in cereals, Northern USA } \\
\uparrow \mathrm{T}^{\circ} \mathrm{C} \Rightarrow \downarrow \text { abundance of } S \text {. pruininus in cereals }\end{array}$ & {$[21,22,24,25,53]$} \\
\hline Rainfall & Medium & Depends on the species and the period under consideration & [22-25] \\
\hline \multicolumn{4}{|c|}{ Soil properties } \\
\hline $\begin{array}{l}\text { Organic matter } \\
\text { content }\end{array}$ & Medium-High & $\begin{array}{c}\uparrow \uparrow \mathrm{OM} \Rightarrow \uparrow \text { risk } \\
\text { High risk when } \mathrm{OM}>5 \% \text { (Agriotes spp.) }\end{array}$ & {$[23-25,52]$} \\
\hline Soil moisture & Medium-High & $\begin{array}{c}\uparrow \text { mean frequency of days above a moisture threshold } \Rightarrow \\
\downarrow \text { wireworm occurrence (IA, USA) } \\
\text { Soil-dependent }\end{array}$ & {$[21,22]$} \\
\hline $\mathrm{pH}$ & Medium & $\begin{array}{c}\text { Low } \mathrm{pH} \Rightarrow \uparrow \text { damage risk in maize (Agriotes spp.) } \\
\text { Increased abundance in L. californicus with higher soil } \mathrm{pH}\end{array}$ & {$[24,25,53]$} \\
\hline Texture & Low & Loam soil $\Rightarrow \downarrow$ damage risk & {$[22-25,52,53]$} \\
\hline Drainage & Medium & Bad drainage $\Rightarrow \downarrow$ damage risk & {$[23,25]$} \\
\hline \multicolumn{4}{|c|}{ Current agricultural practices } \\
\hline Sowing date & Medium & Late sowing (maize) $\Rightarrow \uparrow$ risk & {$[23,25,52]$} \\
\hline Tillage & Medium-High & Ploughing during summer $\Rightarrow \downarrow$ damage risk in sweet potato & [54] \\
\hline Fertilizer application & Low & $\begin{array}{l}\text { Slight decrease in damage caused by Agriotes spp. in maize if } \\
\text { fertilization compared to none }\end{array}$ & [25] \\
\hline \multicolumn{4}{|c|}{ Past agricultural practices } \\
\hline Tillage & Medium-High & $\begin{array}{l}\text { Intense tillage decreases damage risk compared to } \\
\text { reduced tillage }\end{array}$ & [55] \\
\hline \multicolumn{4}{|c|}{ Field configuration } \\
\hline Topography & Low & No significant effect & {$[25,32]$} \\
\hline Exposition & Low & $\begin{array}{l}\text { Very weak difference in damage caused by Agriotes spp. } \\
\text { in maize }\end{array}$ & {$[25,32]$} \\
\hline
\end{tabular}


Table 1. Cont.

\begin{tabular}{|c|c|c|c|}
\hline Risk Factor & $\begin{array}{l}\text { Potential for } \\
\text { Increasing } \\
\text { Damage Risk }\end{array}$ & Factor Effect & Reference \\
\hline \multicolumn{4}{|c|}{ Field history } \\
\hline Historic of meadows & High & $\begin{array}{l}\text { Long-lasting meadow favorable to wireworm damage in maize } \\
\text { (community of Agriotes species) }\end{array}$ & {$[23,25,52]$} \\
\hline Crop rotation type & High & $\begin{array}{l}\text { Rotation including meadows and second crops } \\
\quad \Rightarrow \uparrow \text { damage risk in maize (Agriotes spp.) }\end{array}$ & {$[23,25,52]$} \\
\hline \multicolumn{4}{|c|}{ Landscape context } \\
\hline $\begin{array}{l}\text { Meadow (or grassy } \\
\text { field margins) } \\
\text { adjacency }\end{array}$ & Medium & Presence of adjacent meadow $\Rightarrow \uparrow$ risk & {$[23,25,52,56]$} \\
\hline \multicolumn{4}{|c|}{ Species occurrence } \\
\hline Species identity & High & $\begin{array}{l}\text { Level of damage in maize fields in Italy: A.brevis most harmful, } \\
\text { then } A \text {. sordidus and } A \text {. ustulatus } \\
\text { Different best predictors in Agriotes wireworm abundance in } \\
\text { Croatia. E.g.: A. brevis } \rightarrow \text { previous crop grown; } A \text {. } \\
\text { sputator } \rightarrow \text { rainfall; } \text { A. ustulatus } \rightarrow \text { soil pH and humus } \\
\text { Different predictors of wireworm abundance in northern US } \\
\text { cereal fields. E.g.: L. infuscatus } \rightarrow \text { crop type and soil texture; } \\
\text { L. californicus } \rightarrow \text { crop type, soil moisture, and soil pH }\end{array}$ & {$[24,35,53]$} \\
\hline
\end{tabular}

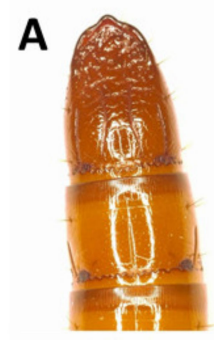

$\mathbf{F}$

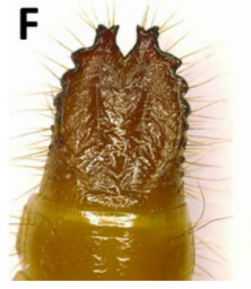

B

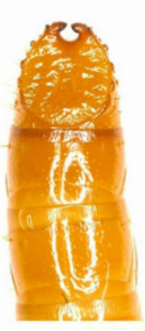

G

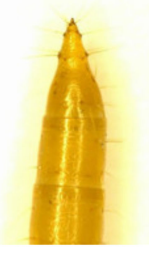

C

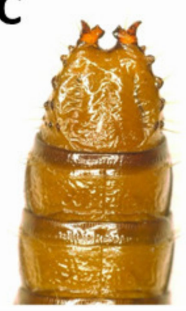

H

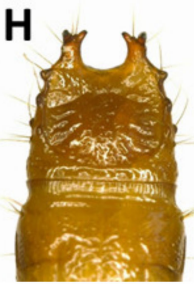

D

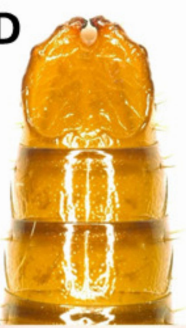

I

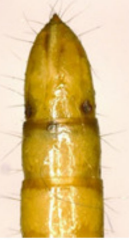

$\mathbf{E}$

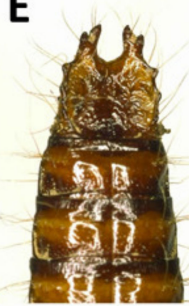

J

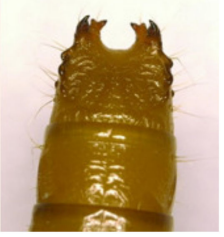

Figure 2. Variability in rear end for wireworm species from different genera. (A) Melanotus punctolineatus, (B) Cidnopus aeruginosus, (C) Athous haemorrhoidalis, (D) Cidnopus pilosus, (E) Prosternon tesselatum, (F) Agrypnus murinus, (G) Adrastus sp., (H) Hemicrepidius niger, (I) Agriotes sputator, and (J) Selatosomus aeneus.

\subsubsection{Decision-Support Systems}

Building on the knowledge of risk factors, a range of models have been able to predict wireworm occurrence based on soil and meteorological data coupled with a hydrologic model [22]; click beetle abundance based on climatic and edaphic factors [24]; wireworm activity based on soil characteristics [21]; their abundance and community structure [53]; correlation between the damage caused in potato fields and landscape structure [56]; and to determine the key climate and agro-environmental factors impacting wireworm damage $[23,25,52]$.

The hypothesis of the vertical distribution of wireworms depending on soil moisture, soil temperature, and soil type was verified by Jung et al. [21], who developed the prognosis model SIMAGRIO-W used as a decision-support system to forecast the (Agriotes spp.) 
wireworm activity based on edaphic properties. Albeit successfully applied in field tests in western Germany, the model performed poorly when it was evaluated in eastern Austria, and research effort is still needed to improve the current model.

Analyzing long-term survey data from maize fields in northern Italy, in which Agriotes brevis, A. sordidus, and A. ustulatus were identified as the predominant pest species, Furlan et al. [23] calculated risk level based on the different weights of the studied risk factors (defined by relative risk values). A simple decision tree was suggested for practical IPM of wireworms [57,58].

The decision-support system VFF-QC (web application: https://cerom.qc.ca/vffqc/, accessed on 9th of May 2021) was originally developed in Quebec (Canada) from a huge database that included more than 800 fields (maize, soybean, cereals, and grasslands), which were characterized by a set of factors (e.g., agricultural practices, soil type, humidity, and organic matter content) and wireworm trapping between 2011 and 2016 [59]. A predictive model based on boosted regression trees assessed the risk level (low, moderate, or high) of finding wireworms in abundance and determined if the field had reached a threshold that would justify treatment. To the best of our knowledge, VFF-QC is the most-used decision-support system for wireworm risk assessment, partly due to rules adopted in 2018 by the Government of Québec that force agronomists to justify the need for seed treatment before prescribing or recommending them to growers.

Using a similar statistical approach, Poggi et al. [25] examined the relative influence of putative key explanatory variables on wireworm damage in maize fields and derived a model for the prediction of the damage risk; they also assessed their model's relevance in providing the cornerstone of a decision support system for the management of damage caused by wireworms in maize crops.

As a whole, these decision-support systems rely on correlative approaches that unravel the potential of a dynamic landscape to shape wireworm populations and eventually crop damages. The development of models that describe the mechanisms driving wireworm colonization, and subsequently elucidate the ecological processes that operate at the landscape scale, remains an avenue for future research.

\subsection{Monitoring and Thresholds}

\subsubsection{Adult Monitoring}

Monitoring soil-dwelling pests is difficult and expensive; thus, efforts have been made to assess population levels of click beetles in the hope of inferring larval abundances or crop damage. The identification of click beetle pheromone goes back to the 1970s in the USA for Limonius species [60,61] and the 1990s in Europe for Agriotes species [62]. Pentanoic acid and hexanoic acid were identified as pheromone compounds for Limonius species. Esters of geraniol are the main components of Agriotes natural sex pheromones [63], given that female pheromone glands contain up to 24 substances [62]. Varying the mixture formulation allows each species to be caught selectively or, alternatively, several of them to be attracted to the same trap [64]. Recently, several kinds of pheromone traps have been developed and used as research tools to monitor populations in both Europe and North America $[24,26,65]$. The female sex pheromones of most major European click-beetle pest species (A. brevis, A. lineatus, A. obscurus, A.proximus, A. rufipalpis, A. sordidus, A. sputator, A. ustulatus, A. litigiosus) have been characterized [64]. YATLORF (Yf) sex pheromone traps (Figure $3 \mathrm{~A}$ ) were designed for a range of Agriotes species, including all of the most harmful ones in Europe and part of the Agriotes pests in North America. In addition, a groundbased pheromone trap for monitoring Agriotes lineatus and A. obscurus was developed to catch A. obscurus and A. lineatus in North America [66]. The apparent ease with which pheromones can be used and their potential as a pest management tool have made them attractive for pest monitoring. However, relating click beetles' catches to larval densities requires a good understanding of the pest behavior, pheromone lure reach, and effects of various abiotic factors on trapping [67]. Pheromone traps for A. lineatus and A. obscurus may have a very short attraction range (below $10 \mathrm{~m}$ ) [68,69] with no directional bias [70,71]. 
Significant association was found between male click-beetle catches in pheromone traps and subsequent wireworm abundance and maize damage in the nearby area for three species: A. brevis, A. sordidus, and A. ustulatus [57]. For example, when Yf $A$. ustulatus catches exceeded 1000 beetles per season, there was a 20 -fold higher probability that the trapped wireworm density exceeded five larvae per trap. The procedure and thresholds described in Furlan et al. [57] allow both farm-scale and area-wide monitoring, resulting in the drawing of risk maps in cultivated areas and enabling IPM of wireworms to be implemented at a low cost. They make wireworm risk assessment highly reliable, especially when it is associated with agronomic risk factor assessment. In contrast with these results, Benefer et al. [72] concluded that the proportion and distribution of adult male A. lineatus, A. obscurus, and A. sputator species may give a very misleading picture of the proportion and distribution of wireworm species in the soil, at least when they are caught with sex pheromone traps. However, this study had major constraints, including the fact that fields were observed for one year only while click beetles are associated with wireworm populations in the subsequent years. A longer period of study using more consistent methods might have revealed significant associations between click beetles trapped in previous years and wireworm population levels at year zero. In any case, as noted in a review on their use [73], pheromone traps are sensitive enough to detect low-density populations, and trapping systems are able to inform growers about the presence or absence of wireworm infestation.
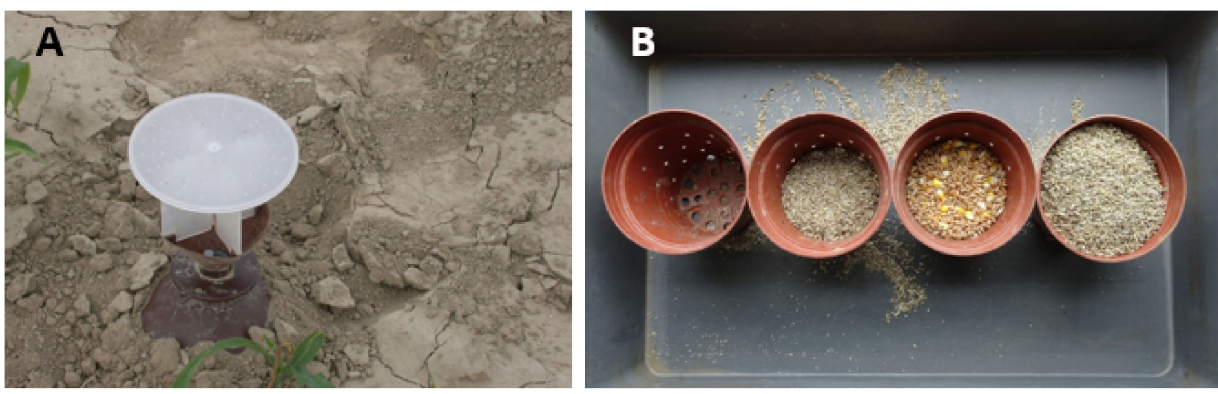

Figure 3. Illustrations of trapping systems. (A) Click-beetle pheromone trap YATLORF. (B) Wireworm bait trap (right pot) and sequential filling of the trap with an empty trap (left pot), a trap with a layer of vermiculite (second pot from left), a trap with a layer of vermiculite and a layer of germinating maize and wheat (second pot from the right).

\subsubsection{Larval Monitoring}

A considerable amount of work has been done in North America and Europe to assess the potential of replacing time-consuming soil sampling with in-field wireworm bait stations [32]. Due to the sampling effort they require and the non-random distribution of the larvae in fields [30], soil sampling is of little interest [32]. Bait systems utilize the attraction of wireworms by the $\mathrm{CO}_{2}$ given off by respiring seeds [74]. Wireworms probably perceive $\mathrm{CO}_{2}$ via clusters of sensilla on the maxillary and labial palps [75]. This probably accounts for the fact that although a large range of vegetable- and cereal-based baits have been tested, baits based on germinating cereal seeds tend to be the most effective [32,76]. In addition, baits based on germinating cereal seeds put in pots (Figure 3B), proved to be an unbiased, time-saving monitoring tool for Agriotes wireworms. Since significantly more larvae are found inside the pot than in the other trap types (i.e., plates and meshbags), this method can be used without the time-consuming evaluation of the surrounding soil cores [77]. This trap design proved to be effective for attracting non-Agriotes species (Aeolus mellillus, Limonius californicus, L. infuscatus) as well [78]. The catch potential of pot baits can be augmented by increasing the number of pot holes [79]. Various techniques for improving the efficacy of wireworm bait systems have been tested. These include covering the bait with plastic $[80,81]$ to raise the soil temperature. The trap designed by Chabert and Blot [80], a modified version of the trap described by Kirfman et al. [81], 
comprises a $650 \mathrm{~mL}$ plastic pot $(10 \mathrm{~cm}$ in diameter) with holes (the ordinary number of those used for tree nursery) in the bottom. The pots are filled with vermiculite, $30 \mathrm{~mL}$ of wheat seeds, and $30 \mathrm{~mL}$ of maize seeds; they are then moistened before being placed into the soil $4-5 \mathrm{~cm}$ below the soil surface, after which they are covered with an $18 \mathrm{~cm}$ diameter plastic lid placed 1-2 cm above the pot rim. These traps have been used long term following a standardized procedure by Furlan [35]: traps were hand-sorted after 10 days when the average temperature $10 \mathrm{~cm}$ beneath the surface was above $8{ }^{\circ} \mathrm{C}[9,10]$ to ensure that the bait traps stayed in the soil for an equal period of wireworm activity. The final number of larvae was assessed under the aforementioned conditions, regardless of larvae behavior on individual days. Population levels should be assessed only when humidity is close to field water capacity. Indeed, dry top-soil forces larvae to burrow deep beneath the surface, away from the bait traps [9], and high humidity (flooding in extreme cases) prevents larval activity since all the soil pores are full of water and contain no oxygen.

\subsubsection{IPM Thresholds}

IPM implementation needs a standardized monitoring method combined with reliable damage thresholds. The aforementioned bait-trap monitoring method has given reliable results over sites and years and might be considered as a standard both for ordinary wireworm IPM implementation and for the assessment of damage thresholds for other wireworm species/crop combinations.

Although increasing literature about wireworms has been published over the last few years (Figure 1), to our knowledge, only four papers report practical IPM damage thresholds, with them being restricted to five species and two crops: Melanotus communis thresholds in sugarcane crops [82], Agriotes brevis, A. sordidus, A. ustulatus [35,57], and A. lineatus [80] in maize crops. Published thresholds are summarized in Table 2. Other papers supply information about crop susceptibility to wireworms that allows an indirect estimation of damage thresholds. Furlan et al. [20] carried out pot trials that introduced the same number of wireworms per pot for different crops. Results showed a large variation in crop susceptibility. A number (6/pot) of wireworms (A. ustulatus, A. sordidus) causing a 50\% maize and sunflower plant loss, had a negligible effect on soybean but killed most of the sugar-beet seedlings. Likewise, Griffith [83] demonstrated differences in plant susceptibility to wireworm attacks in laboratory tests. Larvae of Agriotes spp. were presented with a choice between the seedlings of test plants and of wheat, which is known to be susceptible. Some plants, e.g., onion, were as susceptible as wheat to wireworm attacks, whilst others (mustard, cabbage, French marigold, clover, and flax) were attacked less often. All pea and bean plants exposed to wireworms were attacked, but most tolerated the attacks and continued to grow. Old generic thresholds based on larval density assessed by soil sampling have low scientific reliability and little practical potential [32], one reason being that none of the wireworm species studied were specified.

Table 2. Published damage thresholds according to click-beetle species, crop, and monitoring method.

\begin{tabular}{|c|c|c|c|c|c|c|}
\hline Elateridae Species & Crop & Tool & Threshold (Larvae/Trap) & $\begin{array}{c}\text { Threshold } \\
\text { (Beetles/Season) }\end{array}$ & Threshold & Reference \\
\hline Agriotes brevis & Maize & Bait trap & 1 & & & {$[35,57]$} \\
\hline Agriotes sordidus & Maize & Bait trap & 2 & & & {$[35,57]$} \\
\hline Agriotes ustulatus & Maize & Bait trap & 5 & & & {$[35,57]$} \\
\hline Agriotes lineatus & Maize & Bait trap & 1-2 (seeding before 1st May) & & & {$[80]^{*}$} \\
\hline Agriotes brevis & Maize & Yf pheromone trap & & $210 / 450$ & & [57] \\
\hline Agriotes sordidus & Maize & Yf pheromone trap & & 1100 & & [57] \\
\hline Agriotes ustulatus & Maize & Yf pheromone trap & & 1000 & & [57] \\
\hline Melanotus communis & Sugarcane & $\begin{array}{l}\text { Soil samples taken } \\
\text { in sequence to } 25\end{array}$ & & & $\begin{array}{l}8 \text { wireworms found } \\
\text { in total samples }\end{array}$ & [82] \\
\hline
\end{tabular}

* Derived data published in the cited paper; plant damage was lower than $15 \%$ with $1-2$ wireworms per trap. Wireworm plant damage lower than $15 \%$ in maize should not result in yield reduction [23]. 


\section{Pest Population Management}

The current resurgence of wireworm damage to various crops has resulted in a strong demand for new agroecological methods to control those pests, notably consequential to the reduced availability of pesticides, possibly in response to global changes and pressing demands by the general public for the implementation of more environmentally friendly agricultural practices. Accordingly, continuous advances in the knowledge of click-beetle biology and ecology have led to several new management practices currently being tested or developed. New proposals mostly originate from (1) the field of agricultural sciences, with them promoting relevant cultural or mechanical methods (use of resistant/tolerant crops, design of bespoke tilling strategies or rotation); (2) the field of chemical ecology (use of pheromones for sexual confusion); (3) the field of trophic ecology (biological control); and (4) from the field of landscape ecology (large-scale habitat management to reduce pest pressure at landscape scale).

\subsection{Cultural or Mechanical Control}

\subsubsection{Effect of Rotation}

The first prevention strategy when controlling wireworm populations is to plan a diversified ecosystem that includes a rich rotation with crops and cover crops placed in the most suitable positions. Crops susceptible to wireworm damage should be placed after crops that do not favor or that reduce wireworm populations (e.g., incorporating barley and oats into crop rotations can reduce wireworm attacks [84]). Crop diversification can benefit wireworm control. For instance, mustard, cabbage, French marigold, clover, and flax are less susceptible to attack, while pea and bean plants tolerate attacks [83]. Hence, large intensively tilled (e.g., hoed) inter-row crops and/or biocidal cover crops directly reduce wireworm populations $[85,86]$. Generally speaking, cover-crop choice can contribute to wireworm cultural control both through its effect on soil biodiversity and ecosystem stability and through its biofumigant/biocidal effect. Crop choice can contribute to wireworm mechanical control by increasing larval mortality, either due to tillage interventions when preparing sowing beds or to hoeing in large inter-row crops.

\subsubsection{Effect of Tilling}

As the life cycles of wireworm species last several years and take place largely in soil, tillage may impact several of their life-history traits. During the oviposition period in spring, females lay their eggs in the top soil-layer $[10,20]$ in a steady environment, such as litter or grass, whenever possible, because of their own sensitivity to temperature fluctuations [6] and their eggs' sensitivity to desiccation. After hatching, larvae are exposed to soil tillage, in particular to ploughing, making them vulnerable to predation [55] or desiccation [87]. In 1949, Salt and Hollick [55] conducted a five-year experiment, which highlighted that the decline in wireworms was accompanied by an outstanding change in the distribution of larvae sizes, reflected by a decrease in the number of young larvae. It is currently acknowledged that, due to a lack of soil cover, oviposition might be reduced on row-crop compared with grassland [19,32]. Seal et al. [54] found that ploughing three times during the summer reduced wireworms collected at bait traps from 1.75 per bait trap to 0.2 per bait trap, compared to no change in unploughed control plots. This reduction was attributed to exposure to bird predation and desiccation. Larval mortality depends on tillage timing, which should match the egg-laying and first instar larvae periods, which are the most susceptible to unfavorable soil conditions. The best tillage timing for interfering with wireworm population dynamics varies with the species life-cycle. For example, in Italy, overwintering A. sordidus adults emerge from their cells in the soil from late Marchearly April and start to lay eggs from May onwards [10]; thus, susceptible instars (eggs and young larvae) occur in the soil from May to June, usually peaking in May. Therefore, tillage from mid-May to late June, as preparation of seed beds for the subsequent crop and hoeing in row crops can dramatically reduce subsequent wireworm populations. 


\subsubsection{Effect of Water Management}

The effect of drying and flooding has been studied mainly on the American West Coast [16,88-90] and in British Columbia [91]. Irrigation timing may play a role in interfering with wireworm population dynamics. The drying of the top-most soil layer just after eggs are laid can be an effective means of controlling wireworms. Soil drying could be achieved by withholding irrigation from alfalfa before harvest, but it is nevertheless more effective in lighter sandy soils [88]. The main challenge of water management as a control lever is the different response of species according to soil moisture. While Ctenicera pruinina (Horn) has long been a pest of dryland wheat [92] and disappears as a pest when fields are converted to continual irrigation [93], Limonius californicus do not survive well in dry soil and prefer soil with 8-16 percent moisture [16,89]. Another challenge is the ability of some species to adapt to soil moisture [94]. Despite damage often being reported in soils that flood in the winter, field flooding can effectively reduce Agriotes wireworm populations when combined with high temperatures [91]. Lane and Jones [95] highlighted the relationship between soil moisture and temperature on the mortality of Limonius californicus larvae. At $30{ }^{\circ} \mathrm{C}$, all larvae submerged under soil and water were killed in four days, whereas only 26 percent of larvae died after 21 days when temperatures dropped below $10{ }^{\circ} \mathrm{C}$. It was also demonstrated that alternating periods of soil flooding and drying is effective for reducing wireworms [96].

\subsection{Semiochemical Control}

Since the 1970s, regular progress has been made in elucidating the composition of clickbeetle pheromones. Synthetic mixtures are now available for several species of agricultural importance, opening new perspectives for using them in wireworm monitoring or even developing new control strategies that rely on adult sexual confusion or mass-trapping.

Besides their potential use for establishing wireworm populations (see Section 2.2), pheromone traps might be used to reduce populations, either through mating disruption or through mass-trapping. Mass-trapping was successfully implemented in Japan to control Melanotus okinawensis on sugarcane, with adult densities being reduced by approximately $90 \%$ after six years of mass-trapping with 10 pheromone traps per hectare [97]. By contrast, a similar study observed no reduction in Melanotus sakishimensis abundance [98]. For Agriotes species, the limited attraction range of pheromone traps exacerbates the challenge of mass-trapping and requires a dense network of traps to be set up if populations are to be reduced. Hicks and Blackshaw [70] estimated that suppressing Agriotes populations using mass trapping would be prohibitively expensive ( $2755 € /$ ha/year), requiring four years of trapping with 10 traps/ha for A.obscurus, 15 traps/ha for A.obscurus, and $\mathrm{m}$ for A. sputator. In a long-term experiment on potatoes, Sufyan et al. [99] captured 12,000 specimens belonging to three Agriotes species over a period of five consecutive years without any effect on the subsequent larval densities or on potato damage. In 2014, Vernon et al. [100] indicated that arrays of traps spaced $3 \mathrm{~m}$ apart potentially disrupted mating but also showed that only $85.6 \%$ of the released A. obscurus were recaptured. As pointed out by Ritter and Richter [101], mating disruption may be easier for short-lived adult populations that are protandrous and exhibit a short, well-defined swarming period. Work is still in progress on the use of pheromone traps [102] to estimate wireworm population levels for IPM programs $[57,68]$.

\subsection{Biological Control of Wireworms}

Inundative releases of natural enemies to control pests have been implemented for many years and may be a way to control wireworms in the future. In Europe, this is successfully performed by mass releases of Trichogramma wasps against the European Corn Borer (Ostrinia nubilalis) in Germany, a Metarrhizium product for the control of June chafer larvae (Phyllopertha horticola) in Switzerland, or a Metarrhizium granule for control of black vine weevil larvae (Otiorhynchus sulcatus) as well as a variety of uses of entomopathogenic nematodes against different horticultural pests. Van Lenteren et al. [103] 
describe a wide variety of further uses worldwide. Kleespiess et al. [104] showed there are also some potential candidates for wireworm control. Currently, the main focus is on entomopathogenic fungi, with some research also being done on nematodes and combinations of different organisms.

\subsubsection{Wireworm Predators}

Numerous vertebrates are predators of elaterid larvae and adults, but birds seem to be the major group with more than 100 different bird species mentioned for Europe and North America [105-107]. Mammals, plus amphibian and reptilian predators, are probably of lower importance than birds $[105,106]$. However, general predation by vertebrates is unlikely to substantially lower wireworm numbers over a large area, even though attempts to use poultry for this purpose were made early on [106]. Predation of click beetles and wireworms by other arthropods, especially by large predatory beetles (Carabidae, Cicindelidae, Staphylinidae) or predatory flies (Asilidae, Therevidae), has occasionally been observed [106,108-110], but as unspecialized predators, they only remove occasional wireworms or beetles. Agriotes larvae are predominately, but not exclusively, herbivorous, while species of other genera are predominantly or fully carnivorous [110-112].

\subsubsection{Wireworm Parasitoids and Parasites}

Generally, wireworms with infections or parasitoids are not commonly found in the field [104,113]. Studies listed by Subklew [106] found no parasitoid in Horistonotus uhleri, Limonius californicus, Sinodactylus cinnamoneus, and Selatosomus aeripennis destructor (formerly Ctenicera aeripennis destructor). Kleespies et al. [104] examined about 4000 Agriotes spp. larvae mainly from Germany. Of these wireworms, only 25 were infected by entomopathogenic fungi, 29 by nematodes, and 66 by bacteria.

Entomopathogenic bacteria (EPB) appear to be the least tested group of microorganisms against wireworms, although they have been known for considerable time. Langenbuch [114] mentioned an unknown bacteriosis in wireworms. Recently a new bacterium (Rickettsiella agriotidis) was found and described [104,115], but no information has been published about its potential associated mortality. Danismaszoglu et al. [116] found that some members of the bacterial flora of Agriotes lineatus and related bacteria caused mortality up to $100 \%$. Mites, in most cases probably from the family Tyroglyphidae, commonly occur on field-collected wireworms (Figure 4A). Whether these mites have a parasitic or phoretic connection to the wireworms is unknown, but the latter appears more likely [105].

\subsubsection{Hymenoptera}

Few hymenopteran parasitoids of soil-inhabiting wireworms are known. For Europe, Subklew [106] lists records mainly of Paracodrus apterogynus (Proctotrupidae), but other Proctotrupidae and partly unidentified Hymenoptera also appear. P. apterogynus is a gregarious parasitoid with several individuals (Figure 4B), but a low percentage of males, emerging from a single wireworm [117]. Known hosts of P. apterogynus are Agriotes obscurus, Agriotes lineatus, and Athous sp. [113,117-120], indicating that different genera and species are attacked. Another species, Pristocera depressa (Bethylidae), is a solitary parasitoid of Agriotes obscurus [121] and perhaps further species. Females of P. apterogynus and P. depressa are wingless, indicating that both species search for their wireworm hosts underground. According to D'Aguilar [113], only five of several thousand Agriotes larvae from a site in Brittany (France) were parasitized. The parasitism rate seems to be similarly low in Germany, with only two of several thousand wireworms from all over the country being parasitized by a gregarious hymenopteran, most likely P. apterogynus (Lehmhus, unpublished). In a few cases, parasitoid Diptera larvae were also found $[106,122]$. Due both to the rare occurrence of insect parasitoids in economically relevant wireworms and to specific parasitoid biology, they are unlikely to be suitable for mass rearing and augmentative biocontrol. 

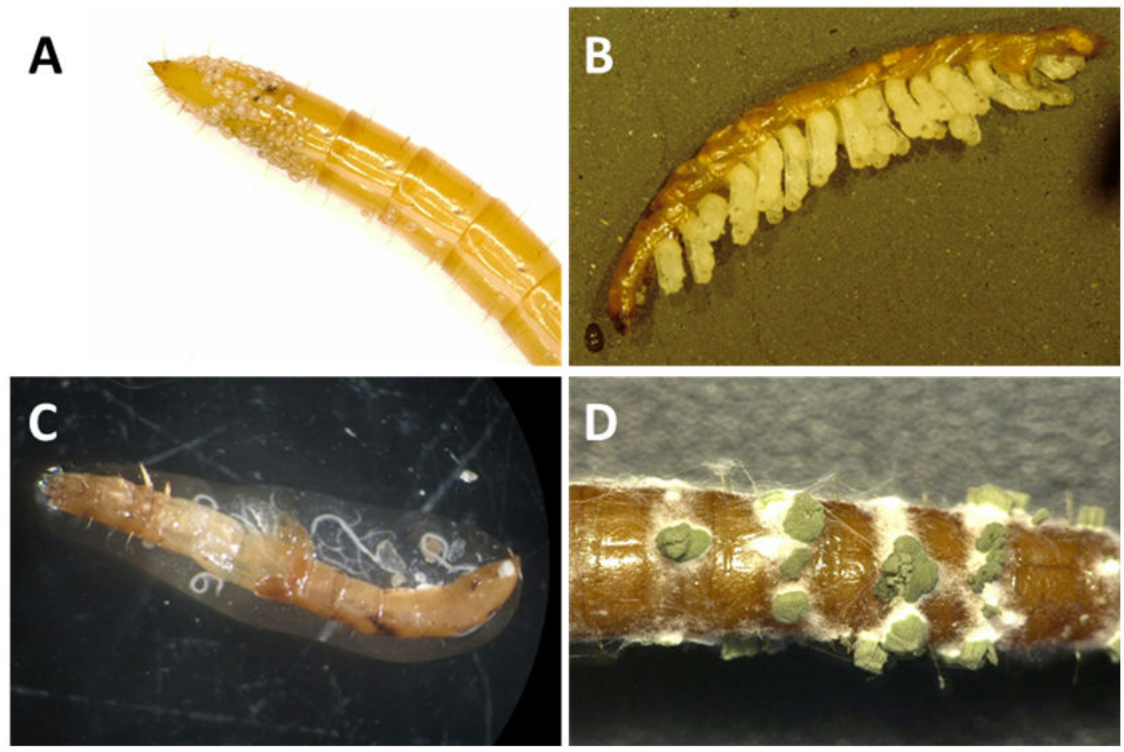

Figure 4. Illustrations of wireworm biocontrol agents. (A) Mite infestation of an Agriotes ustulatus wireworm; it is unclear if these mites are parasitic or phoretic, but heavy infestations appear to affect wireworms negatively; (B) Agriotes sp. wireworm with gregarious hymenopteran parasitoid, most likely Paracodrus apterogynus; (C) Agriotes sordidus infested by the nematode S. boemarei (strain FRA48, Lee etal. 2009) carrying the symbiotic bacterium Xenorhabdus kozodoii FR48; and (D) Agriotes lineatus wireworm with Metarrhizium brunneum infestation. Photographs A, B, D: JKI. Photograph C: INRAE-DGIMI.

\subsubsection{Nematodes}

Nematodes of the family Mermithidae parasitize arthropods, mainly insects with at least 15 different orders as hosts [123]. The use of Mermithidae has been discussed for biocontrol of mosquitoes [124], but they are occasionally also found in click beetles or wireworms $[122,125]$. Considering the low densities and propagation difficulties, they are not considered to be suitable candidates for wireworm control.

Entomopathogenic nematodes (EPN) from the genera Steinernema and Heterorhabditis (Nematoda: Steinernematidae, Heterorhabditidae) with their bacterial symbionts Xenorhabdus spp. and Photorhabdus spp. (Gram-negative Enterobacteriaceae) are bacterium-nematode pairs and pathogenic to a broad range of insects (Figure 4C). Species from both nematode genera have also been successfully implemented in biological control of insect pests throughout the world [126]. However, wireworms often show very low susceptibility [127] or are sometimes even considered to be resistant to EPN [128]. This may partly be due to unsuitable species combinations, as there are also several cases with successful infection by EPN and damage reduction in the field [129-131]. For example, larvae of A. lineatus were reduced by Heterorhabditis bacteriophora and Steinernema carpocapsae, but not by Steinernema feltiae [132,133]. Lehmhus [42] showed differences in mortality for the same three EPN when they attacked four common European wireworms Agriotes lineatus, A. obscurus, A. sputator, and Selatosomus aeneus. All EPN did cause mortality in the three Agriotes species, but $S$. feltiae failed to cause mortality in S. aeneus, which was also the least sensitive wireworm to the other EPN. According to Campos-Herrera and Gutiérrez [127], a Spanish isolate of Steinernema feltiae performed poorly against Agriotes sordidus. Ansari et al. [132] demonstrated that there were considerable differences in the mortality of a wireworm (Agriotes lineatus) caused by different EPN species and even by different strains of a single EPN species (0-67\% mortality). Rahatkah et al. [134] showed that after injection of infectious juveniles, the immune reactions of the same wireworm species (Agriotes lineatus) to different nematode species (Heterorhabditis bacteriophora and Steinernema carpocapsae) differed with a higher encapsulation of infectious juveniles from the former, which may be one reason for nematode strains performing differently. Morton and Garcia del Pino [135] 
found that the mortality of Agriotes obscurus in the lab was dependent both on nematode species and on infectious juvenile dose rates, while under field conditions, a dose of $100 \mathrm{IJs} / \mathrm{cm}^{2}$ and the best performing strain Steinernema carpocapsae (Weiser) B14 still resulted in nearly 50\% mortality. These results indicate that in entomopathogenic nematodes, the control achieved against wireworms is, besides the environmental factors discussed below, dependent on the concentration of infectious juveniles and on the combination of nematode strain and wireworm species.

\subsubsection{Fungi}

In the field, fungal pathogens can occasionally influence wireworm or click beetle survival greatly. In Switzerland, Zoophthora elateridiphaga was described by Turian [136] as attacking A. sputator. According to Keller [137], infection rates of A. sputator click beetles in Switzerland with Zoophthora elateridiphaga (Entomophthoraceae) varied between $72.6 \%$ and $100 \%$. The same fungal pathogen occurred at one location near Braunschweig, Northern Germany, in A. obscurus and A. sputator click beetles, but with only about $10 \%$ becoming infected (Lehmhus personal observation 2013, determination of pathogen R. Kleespiess). Entomophthoraceae are comparatively sensitive, difficult to preserve and propagate, and unsuitable for most spray applications, and thus achieving long-term viability is often quite difficult [138]. However, as Keller [139] observed Z. elateridiphaga also attacking adults of Notostira elongata (Miridae) and achieving growth of colonies on Sabouraud Dextrose Agar (SDA), the host range of this fungus may be less narrow and cultivation less difficult than generally thought. A remaining problem is that attacks by this fungus are directed at adults.

More promising are the entomopathogenic fungi Beauveria bassiana (Cordicipitaceae) and Metarrhizium anisopliae sensu lato (Clavicipitaceae), including related forms like M. brunneum (Figure 4D). These naturally soil-inhabiting fungi are widely recognized as interesting biological control agents against several insect pests [140] and have been known to kill wireworms for more than 100 years [105]. The mechanisms involved in the infection process in wireworms have already been described in detail (e.g., [141,142]). Trials have been conducted with several different strains of both fungi (Beauveria bassiana and Metarrhizium anisopliae sensu lato, including M. brunneum) at different application rates and with different wireworm species both in the field and in the laboratory. The results were quite variable. A commercial product containing a Beauveria bassiana strain reached efficacy values between 54\% and 94\% against Agriotes spp. in the field in Northern Italy [143], but in other regions, no differences between potato plots treated with this product and untreated plots were observed [144,145]. Eckard et al. [146] showed differences in mortality for three different strains of Metarrhizium brunneum in the three most common European species: Agriotes lineatus, Agriotes obscurus, and Agriotes sputator. Species and stages of five North American elaterid species differed markedly in resistance to attack by a strain of each of the two entomopathogenic fungi Metarrhizium anisopliae and Beauveria bassiana [147]. Kabaluk et al. [122] tested 14 isolates of Metarhizium anisopliae against three species of wireworms. The North American Ctenicera pruinosa was susceptible to most isolates, while Agriotes obscurus was highly susceptible to four isolates, and Agriotes lineatus was the least susceptible species. Under these circumstances, it is clear that a suitable combination of wireworm species found in the field and EPF strain used is needed to achieve high control effects. A further constraint may be that some bacterial symbionts of wireworms could actively suppress the infection by entomopathogenic fungi [148], which may explain control failures when environmental conditions and the combination of species and strain seem to fit.

\subsubsection{EPN and EPF Use Generally}

Both environmental and behavioral factors will further affect the infection of wireworms with entomopathogens (EPN and EPF likewise). The retaining of sufficient moisture is indispensable for the growth of entomopathogenic fungi [149] and has to be solved some- 
how for reliable control. According to Kabaluk et al. [122], Rogge et al. [150], and Kabaluk and Ericcson (2007), additional factors such as temperature, exposure time, conidia soil concentration, and food availability also affect mortality rates of wireworms when exposed to Metarrhizium anisopliae. However, while lower temperatures slow down the spread of wireworm infection [151], the desiccation commonly experienced under summer conditions might affect the viability of EPF in soil. Additionally, wireworms can perform seasonal movements to forage in favorable conditions and to avoid unfavorable ones [9,32,50,114,152-155], meaning that wireworms may escape a biocontrol agent used when the lethal potential of an entomopathogen is not reached shortly after application. For example, infection late in the potato-growing season would probably not prevent damage to daughter tubers. Therefore, the temperature conditions under which the infection cycle of an isolate has its optimum must be considered. For early season applications, a more northern fungal isolate adapted to lower temperatures [156] might even enable crop protection early in the year for such crops that need to be protected as young plants. A temperature effect on the pathogenicity of EPN is also known [157,158], albeit not documented for pathogenicity against wireworms. A further constraint is that the soil type can also influence the effectiveness of biological wireworm control [159]. This has also been described for other insects, partly with contradicting results of higher EPN efficacy in sandy soil than in clay soil, or vice versa [160-162].

In contrast, the origin of inoculum had no significant effect on the virulence of a Metarrhizium brunneum strain. The mortality of wireworms treated with spores from host cadavers was similar to the mortality of wireworms treated with spores from a modified Sabouraud Dextrose Agar (SDA) after ten sub-cultivations [146]. Therefore, in general, virulence should not be affected by the conidia production method.

According to Ericsson et al. [163], the biological insecticide Spinosad interacted synergistically with Metarhizium anisopliae against Agriotes lineatus and A. obscurus, indicating that combinations with a second stressor (insecticide, EPN, or EPF) might enhance biological control. <the synergistic or additive effects of combined use of EPN, EPF, and EPB have been shown for several other pests [164-167].

Several studies [168-172] show that the application pattern is another important point to consider, with banded or spot application being particularly useful.

Nevertheless, in many cases, results achieved by biological control are not yet satisfactory compared to an effectiveness between $50-90 \%$ achieved by plant protection products based on the insecticides carbosulfan, fonofos, findane, fipronil, imidacloprid, thiamethoxam, or bifenthrin used in the past $[143,173,174]$. However, even an array of insecticides tested on five different wireworm species in three elaterid genera demonstrates that there are clear differences in mechanisms, symptoms, and mortality, with even chemical insecticides failing to remove all wireworms [175].

\subsubsection{Attract and Kill-A Possible Solution?}

The key issue is how the effect of an entomopathogen could be further enhanced for reliable control. One idea is the development of an attract-and-kill strategy that exploits the foraging behavior of herbivorous insects. This means the combination of a compound attracting the wireworms directly to the product and a killing compound that disposes of them effectively. Such attract-and-kill formulations could be used to enhance the effect of both EPN and EPF, as the wireworms are lured directly to the entomopathogen.

$\mathrm{CO}_{2}$ is a known attractant for wireworms [74,176] and other soil insects $[177,178]$. Barsics et al. [179] summarized earlier research that demonstrated the existence of $\mathrm{CO}_{2}$ perception and research on a shorter range working chemosensory sensillae in wireworms. Brandl et al. [172] developed an attract-and-kill system with an alginate capsule with yeast and starch producing $\mathrm{CO}_{2}$ as an attractant, with a Metarrhizium brunneum strain as kill component; as a result, they were able to reduce tuber damage significantly when compared to the control in three out of seven field trials in potato. In four out of seven trials, the potato tuber damage appeared lower in the attract-and-kill when compared to kill 
treatment, but differences were not significant. However, different application scenarios were tested, so the trials are not directly comparable. A resulting formulation is currently the only product in potato against wireworm damage in Germany (emergency registration, restricted acreage). According to Küppers et al. [171], a reduction in damage was achieved with this product at low-to-medium wireworm infestation.

Wireworms are also attracted to plant- or root-produced volatile aldehydes when they are actively foraging [180], similar to several other soil-inhabiting insect herbivores [181]. This or other organic plant compounds could be exploited for an attract-and-kill strategy. La Forgia et al. [182] encapsulated entomopathogenic nematodes with potato extracts as an attractant and feeding stimulant in alginate beads against the wireworm Agriotes sordidus. When compared to conventional EPN application and to beads containing only potato extract, the beads with both potato extract and S. carpocapsae or H. bacteriophora increased mortality rates, significantly only for the latter, indicating the importance of a suitable attractant for effective wireworm control. However, these are the first steps towards an attract-and-kill formulation, and it is possible that a combination of $\mathrm{CO}_{2}$ and root volatiles may enhance the efficacy of the method even further.

Additionally, attract-and-kill strategies using entomopathogens (again Metharizium brunneum spores) as alternatives to chemical pesticides may also be used effectively to interfere with click-beetle populations and subsequent wireworm ones, as suggested by Kabaluk et al. [183]. This might be pursued by using modified pheromone traps that allow beetles to enter back and forth traps containing spore powder. This strategy does not require a 100\% catch, or the vast majority of male beetles to be caught in a short space of time, since the killing agent would spread through the population, coming into increasing contact with both male and female adult beetles. At least in some click beetles, sex pheromones also perform as aggregation pheromones, and they can also attract significant numbers of females, as demonstrated for A. sordidus, A. brevis, and A. ustulatus [184-187]. This may be an additional pathway to increasing entomopathogen infections in click-beetle populations and further reducing wireworm pressure on crops.

\subsubsection{Problem: Different Species of Wireworms}

A general problem in biological control of wireworms is the involvement of several different wireworm species with mixed populations often at the same site [13,32,40,42,46,152,188-190]. When observing the differences in efficacy of a specific EPN or EPF strain against common wireworm species (e.g., $[122,132,146])$, it becomes clear that for biological control in a certain location, we need to know the wireworm species involved. This is not an easy task. Considerable time and expertise are needed for a reliable identification of wireworm species. Both the molecular method (PCR) and the morphological methods have their difficulties, but both produce reliable results for most individuals [13,39,40,72,191]. Additionally, recent molecular research suggested a possible occurrence of cryptic species in some North American wireworms [72,192], which may also affect the efficacy of a biological product. Furthermore, the activity pattern and damage potential of different wireworms in a crop may differ, which could affect the risk a certain species poses for a certain crop $[35,153]$.

Early on, a specific key only for the Elateridae harming agriculture and horticulture needed to be established, as a major part of wireworms are not relevant in agriculture [193] and could be omitted. Keys for wireworms of economic importance only have been provided early in some countries [37,38,45]. Recently, a simple morphological key has been proposed for more common middle European genera in agricultural fields [41], which may be useful for farmers and plant protection service field workers without access to molecular methods. A final solution could be a combined product involving different strains of entomopathogens with sufficient growth at low temperatures, high efficacy against the commonest wireworm species in a region, and additionally an attractant source, applied in furrow at planting. 


\subsection{Naturally Derived Insecticides}

Biocidal meals are practical options for controlling wireworm populations, both as prevention structural measures (wireworm population reduction at a suitable rotation period) and as rescue treatments just before the sowing of susceptible crop; after that, the occurrence of a wireworm density exceeding the threshold has been assessed [85]. They contain the same glusosinolate-myrosinase system described for biocidal cover crops (Section 3.1.1). Their potential can be considered comparable to that of chemical insecticides [85]. In laboratory [10] and pot trials [85], Brassica carinata seed meals caused a larval mortality higher than $80 \%$ and complete maize seedling protection. At large-field scale, both potato and maize crops have been effectively protected. In order to obtain successful practical results in the field, the same conditions described for biofumigant cover crops (Section 3.1.1) need to be fulfilled concurrently. Biocidal meals have become commercial products available for farmers, and practical implementation has already taken place.

\subsection{Habitat Manipulation}

Elaterid species are capable of exploiting both cultivated and uncultivated areas in the agricultural landscape [53]. Their movement from suitable habitats where populations thrive, i.e., source habitats such as grasslands, to vulnerable crops determines the colonization process and eventually crop damage. Thus, habitat connectivity in space and time $[194,195]$ is a key driver of pest dispersal success in dynamic agricultural landscapes. Indeed, numerous studies have demonstrated that the spatial and temporal arrangement of land uses can provide a lever for action to control species abundances with regard to landscape compositional constraints (see for example [196-198]). Nevertheless, implementing such pest control strategies demands an extensive knowledge of pest biology and ecology, notably species-specific life traits such as life-cycle duration and dispersal ability.

The presence of uncultivated area in the field history or in the field vicinity [22-24,56,199] is clearly identified as a risk source in terms of wireworm infestation and/or crop damage; hence, it is often considered by farmers (e.g., managing the crop rotation within a field). More generally, while landscape context has been identified as a risk factor (Section 2.1), habitat manipulation remains underused. In their theoretical study, Poggi et al. [34] addressed the role of grassland in the field history, field neighborhood, and both. They have shown that species with a short life cycle are highly responsive to changes in land use, and that the neighborhood effect strongly relies on assumed dispersal mechanisms (random vs, directed movements). They also illustrated how the arrangement of grassy landscape elements in space and time can mitigate crop infestation by soil-dwelling pests, thereby emphasizing the relevance of managing grassland regimes. Thus, habitat manipulation may provide another component within an IPM approach.

\section{Crop Damage Management}

Wireworms are among the most destructive soil insect pests on potatoes and other crops, including corn and cereals (see Figure 5). Practices targeting limitation of damage despite substantial larval densities rely on identifying optimal planting and harvest conditions, protecting the sensitive crop with attractive companion plants, increasing seeding rates, and planting more tolerant cultivars. 

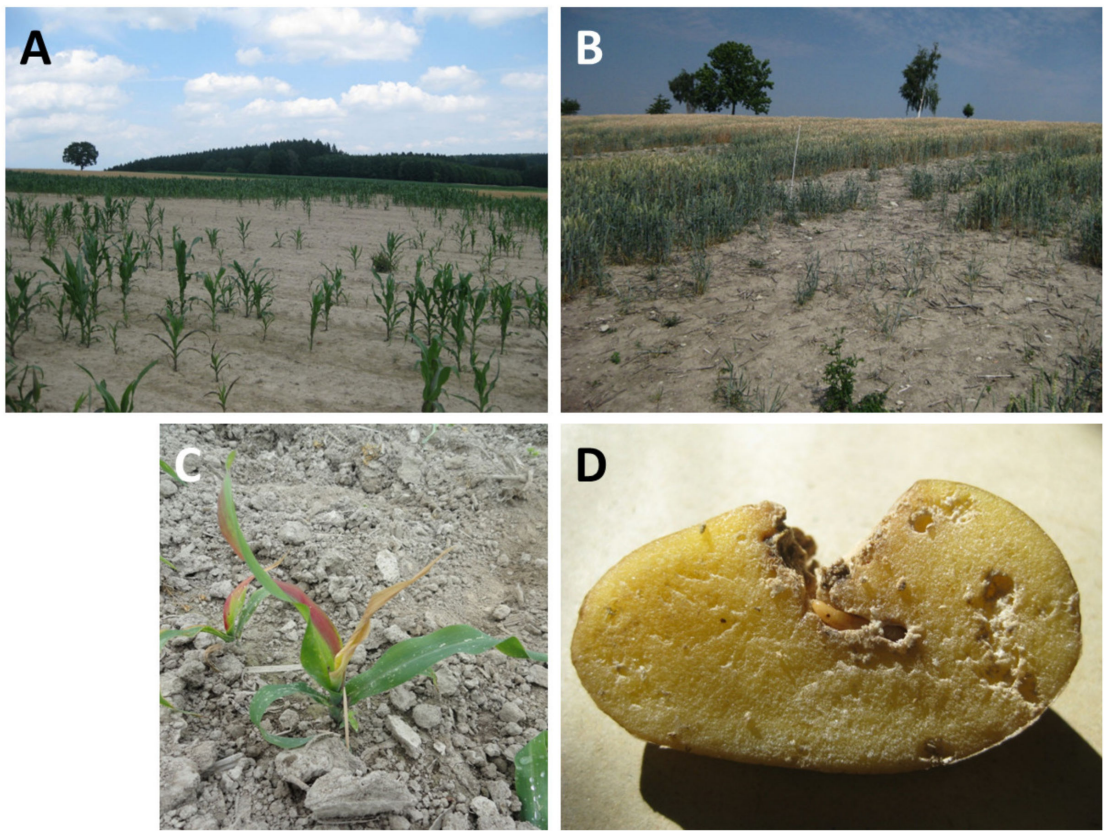

Figure 5. Illustration of crop damage and symptoms. (A) Damage in maize caused by mixed populations of A. obscurus and A. lineatus. (B) Damage in winter wheat caused by A. sputator. (C) Symptoms of wilting on maize small plants. (D) Damage on potato caused by A. obscurus. Photographs A, B, and D: JKI. Photogaph C: Arvalis.

\subsection{Cultural Control}

\subsubsection{Optimal Sowing and Harvest Timing}

If substantial larval density is observed before maize planting, it is common to recommend delaying the sowing date as higher temperatures lead to shorter sensitive crop period, which should allow seedlings to resist damage. As regards planting time strategy, we have to consider that a population's capacity to damage sensitive plants varies with the season, e.g., in late spring, very high $A$. ustulatus populations do not damage maize stands because most of their larvae are in a non-feeding phase [9]. Therefore, adjusting planting times, when possible, to coincide with low pest populations or with non-damaging life stages can be effective. This recommendation cannot be generalized, since it is strictly depending on the species' life-cycle. Furlan et al. [23] showed that late sowing significantly increased damage risk on maize, mainly by A. brevis and A. sordidus, when compared with the ordinary sowing date. They explained this result by biological factors, as late sowing implies that most of the population is in the feeding phase due to higher temperatures accelerating larval molting, while small plants are still susceptible. Saussure et al. [52] also identified sowing date as a minor variable for explaining damage, contrary to the conclusions reached thus far. Poggi et al. [25], however, highlighted that soil temperature at maize sowing date influences damage. In potato production, recent studies in Germany and in Italy have shown that early harvest may reduce tuber damage $[85,200]$. Generally speaking, the less time potatoes stay in the field, the lower the wireworm damage risk; thus, short-cycle varieties may represent another synergic agronomic strategy.

\subsubsection{Resistant Varieties}

As for the variety/hybrid resistance to wireworm attacks, little is known and practically exploited. For example, recent achievements [201] suggest that there is potential for maize variety/hybrid tolerance/resistance to wireworms, but seed bags with this declared feature are unavailable. Likewise, less-susceptible-to-wireworm-feeding potato varieties have been identified, but based on the increasing potato damage claim from farmers reported by researchers [172], it seems that this agronomic strategy has not been exploited significantly. In potato production, several studies [202-205] highlighted reduced incidence 
and severity of wireworm damage according to varieties. For example, Kwon et al. [205] tested 50 potato cultivars for resistance to several wireworm species. Injury rates varied between $80 \%$ and $96 \%$ in susceptible cultivars, and several varieties were found to be highly resistant.

\subsection{Pest Behavior Manipulation: Feeding Pest as an IPM Strategy}

Soil-dwelling wireworms are usually generalist herbivores, feeding on a wide range of species and usually feeding on most abundant species in their habitat [206]. They may also feed on animal prey [112] and be cannibalistic when larval density is too high for food resources $[9,94]$. The orientation of wireworms towards host plants is described as a three-step process $[75,179]$. First, wireworms orient towards carbon dioxide by klinotaxis. The next foraging step involves plant-root volatiles that allow host-specific recognition [207,208]; one example is aldehyde compounds influencing the ability of $A$. sordidus to locate barley roots [180]. The last step consists in the biting and the retention in the root systems containing asparagine, to which wireworms are sensitive, with the wireworms then remaining in the vicinity of the roots [209]. As their feeding phase only lasts $20 \%$ to $30 \%$ of their entire development $[9,10,19]$, a promising and inexpensive pest management strategy could lie in feeding wireworms, thereby luring them away from the crop during the host susceptibility period [210]. Previous highly effective management strategies have tested pest behavior manipulation using trap cropping or companion plants.

\subsubsection{Trap Crops}

Trap crops are plants grown alongside the main crop in order to manipulate insect behavior to prevent pests from reaching the target crop [211]. If a trap crop can be found that lures pests, at least during sensitive growth periods of the main crop, sustainable and long-term management solutions can result. Hokkanen [211] describes approximately forty successful cases of trap crop strategies on several crops. As wireworms are very polyphagous [32], a wide range of trap crops are readily available. Despite limited larval mobility, wireworms have been found to be attracted and concentrated in trap crops placed around main crops [212,213]. In 2000, Vernon et al. [213] showed that trap crops of wheat, planted as trap crops a week before strawberry planting, can effectively reduce wireworm feeding and plant mortality. Landl and Glauninger [214] demonstrated the influence of peas as a trap crop on potatoes, and several studies have demonstrated that wheat intercropped with pea and lentil showed significantly less wireworm damage $[215,216]$. The attractiveness of trap crops, the timing of planting, and the space they occupy are major factors to consider before selecting and using a trap crop.

\subsubsection{Companion Plants: Feeding Pests as an IPM Strategy}

Companion planting is an agronomic strategy that sees the growing together of two plant species that are known to synergistically improve each other's growth. Companion plants can control insect pests either directly, by discouraging pest establishment, or indirectly, by attracting natural enemies that kill the pest. The ideal companion plant can be harvested, providing a direct economic return to the farmer in addition to the indirect value of protecting the target crop. In maize fields, it has been demonstrated that companion plants lure wireworms away from the crop and lead to a significant reduction (up to 50\%) in damage, which is as effective as common chemical products (Belem 13kg/ha) [210,217,218]. Furthermore, meadow incorporation timing, just before crop seeding (e.g., maize), may protect crops from wireworm damage without any further intervention. This effect is due to the fact that soil-incorporated fresh meadow turf is a more attractive wireworm food source than seeds, emerging seedlings, and young plants [219].

\section{Conclusions}

Although many key aspects are still to be made available-the number of missing damage thresholds is astonishing - the bulk of available information allows us to immedi- 
ately implement effective IPM strategies against wireworms. A practical IPM procedure for efficient wireworm management (including damage thresholds) has been described for maize in Europe $[57,58]$. This IPM procedure is currently implemented on thousands of hectares of cultivated land [7]. In Table 3, the IPM tactics and tools currently available for reducing the risk of wireworm crop damage to susceptible crops are classified according to their damage reduction potential and their current implementation status. "Already applied" practices with proven efficiency and practicability can be immediately implemented, while "under development" strategies are promising ones that still need large-scale evaluation and adaptations to variable practical conditions. "Under study" strategies comprise promising ongoing research, with no or negligible practical implementation, but they are being considered for possible future uses.

Table 3. Alternative strategies that can be applied to maintain wireworm density below damage thresholds according to results of continuous monitoring. One or more practices can progressively be applied to push back wireworm population levels. Under study: promising ongoing research but no or negligible practical implementation. Under development: limited practical applications; ongoing evaluations to adapt solution to variable practical conditions. Already applied: significant widespread implementation.

\begin{tabular}{|c|c|c|c|c|c|}
\hline Alternative Strategies & IPM Principles ** & Section Reference & $\begin{array}{c}\text { Damage Reduction } \\
\text { Potential }\end{array}$ & Applicability & $\begin{array}{c}\text { Current } \\
\text { Implementation }\end{array}$ \\
\hline $\begin{array}{l}\text { Continuous monitoring * } \\
\text { integrated with risk } \\
\text { assessment }\end{array}$ & $\begin{array}{l}\text { P2: Monitoring (observation, } \\
\text { forecast, diagnostics) }\end{array}$ & $2.1 / 2.2$ & & High & Already applied \\
\hline $\begin{array}{l}\text { Continuous monitoring * } \\
\text { integrated with risk } \\
\text { assessment }\end{array}$ & $\begin{array}{l}\text { P3: Decision based on monitoring } \\
\text { and thresholds }\end{array}$ & 2.2 .3 & & Medium & Already applied \\
\hline Low risk rotation & $\begin{array}{c}\text { P1: Prevention and suppression } \\
1.2 \text { Rotation }\end{array}$ & 3.1 .1 & High & High & Already applied \\
\hline Tillage & $\begin{array}{c}\text { P1: Prevention and suppression } \\
1.2 \text { Rotation }\end{array}$ & 3.1 & High & High & Already applied \\
\hline Biocidal cover crops & $\begin{array}{l}\text { P1: Prevention and suppression } \\
1.2 \text { Rotation }\end{array}$ & 3.1 & Medium & Medium & Already applied \\
\hline $\begin{array}{l}\text { Identifying optimal } \\
\text { planting/sowing and } \\
\text { harvest conditions }\end{array}$ & $\begin{array}{l}\text { P1: Prevention and suppression } \\
\text { 1.3 Crop management and ecology }\end{array}$ & 3.1 .2 & $\begin{array}{c}\text { Medium } / \text { high } \\
\text { (potato), } \\
\text { low/medium others }\end{array}$ & High & Already applied \\
\hline Biocidal materials & $\begin{array}{c}\text { P4: Intervention } \\
\text { 4.1 Non-chemical methods }\end{array}$ & 3.4 & Medium & Medium & Already applied \\
\hline $\begin{array}{l}\text { Larvae biocontrol using } \\
\text { attract-and-kill device }\end{array}$ & $\begin{array}{c}\text { P4: Intervention } \\
\text { 4.1 Non-chemical methods }\end{array}$ & $3.3 .7 / 3.3 .8$ & Medium/high & Medium & Under development \\
\hline Tolerant varieties & $\begin{array}{l}\text { P1: Prevention and suppression } \\
\text { 1.3 Crop management and ecology }\end{array}$ & 3.1 & $\begin{array}{c}\text { Medium } / \text { high } \\
\text { (potato), } \\
\text { low/medium others }\end{array}$ & Medium & Under study \\
\hline $\begin{array}{l}\text { Adult biocontrol using } \\
\text { attract-and-kill device }\end{array}$ & $\begin{array}{c}\text { P4: Intervention } \\
\text { 4.1 Non-chemical methods }\end{array}$ & 3.3 .7 / 3.3.9 & Medium & Medium & Under study \\
\hline $\begin{array}{l}\text { Larvae biocontrol using } \\
\text { EPN }\end{array}$ & $\begin{array}{c}\text { P4: Intervention } \\
\text { 4.1 Non-chemical methods }\end{array}$ & 3.3.7 / 3.3.10 & Low/Medium & Medium & Under study \\
\hline $\begin{array}{l}\text { Habitat - landscape } \\
\text { modifications }\end{array}$ & $\begin{array}{c}\text { P1: Prevention and suppression } \\
\text { 1.1 Combinations of tactics and } \\
\text { multi-pest approach }\end{array}$ & 3.4 & Medium & Low/medium & Under study \\
\hline $\begin{array}{l}\text { Protecting the sensitive } \\
\text { crop with attractive } \\
\text { companion plants }\end{array}$ & $\begin{array}{l}\text { P1: Prevention and suppression } \\
\text { 1.3 Crop management and ecology }\end{array}$ & 4.2 & Medium & $?$ & Under study \\
\hline
\end{tabular}

The IPM strategy level needed to continuously keep wireworm populations below damage thresholds, and the lowest possible cost can be pursued by implementing "flexible IPM packages". These should be made up of two or more practices applied at the same time, provided that the different practices are compatible and that they have additional effects on wireworm population and crop-damage reduction. No incompatibilities between the strategies listed in Table 3 have been reported. The first fixed IPM practice, common to any flexible package, should be continuous pest population monitoring with low-cost tools, 
such as pheromone traps (see Section 2.2.1), with complementary local bait trap wireworm monitoring before a susceptible crop seeding when needed (see Section 2.2.2).

IPM flexible packages may vary according to population levels assessed with continuous monitoring. Low-risk rotation should be implemented (see Section 3.1), in accordance with the prevalent wireworm species, including non-favoring crops and tillage when susceptible pest instars (eggs and young larvae) occur in the soil. If monitoring still assesses risky population levels and/or significant wireworm crop damage has been observed, other strategies should be added. These include the incorporation of biofumigant defatted seed meals (pellets) or biocidal plants. Farmers should find the package most suitable to their specific conditions and modulate package strategies as per wireworm population dynamics monitored by YATLORf traps (Table 3). Therefore, a general flexible IPM of wireworms should comprise two main phases: (1) a risk assessment that considers all the relevant agronomic and climatic characteristics that can be typically achieved by continuous monitoring of click-beetle populations with pheromone traps. Complementary wireworm field monitoring is advisable when risk assessment has identified the presence of risk factors and/or high beetle populations and/or previous wireworm crop damage; (2) the implementation of one or more of the practices listed in Table 3 in order to maintain or to restore wireworm populations below levels that cause significant damage to the susceptible crops in the planned rotation. Regardless of whether specific damage thresholds are available, farmers might find the IPM flexible package best suited to each homogeneous cultivated area on their farm by modulating preventative and rescue strategies (Table 3) so that susceptible crop damage is negligible. This should also require costs and the overall economic sustainability of alternative strategy implementation to be considered.

In order to make farmers comfortable with IPM implementation risks, insurance tools covering these risks may be particularly useful and supported by legislation (mutual funds). Mutual fund compensation is commensurate with the financial resources of the fund. The fund stock is increased by savings in forecast costs and covers risks that private insurance companies currently do not, e.g., climatic adversities such as flooding and damage by wild animals and pests, just before and after the emergence of arable crops. The first implementations are underway in Italy and the results are promising [220].

While important advances have been recently made, many gaps remain in the setting up of a complete and efficient IPM framework to deal with wireworm issue in crops. Indeed, significant progress is still needed on many aspects of our knowledge. The association between wireworm density and harmfulness to various crops in different conditions is still missing for several species. This impedes the establishment of precise, verifiable thresholds for each crop $\times$ wireworm species in the various cultivated contexts and areas. Knowledge on behavioral ecology of adults remains highly fragmentary, notably concerning their dispersal (distance, orientation) or their choice of egg-laying site. Progress would be useful if we are to better understand colonization processes and to address wireworm risk at landscape scale. Abiotic and biotic soil parameters (e.g., organic matter content) that favor the survival and development of larvae should be specified in order to identify suppressive soils (i.e., soils that maintain wireworm populations at low levels naturally). This would mainly require assessing the main natural causes of larval mortality, including parasitism and predation, and a better understanding of larval trophic ecology and life-cycle. In terms of agricultural sciences, studies on various promising practices, including tilling, use of biofumigants, or setting up companion plants, should be fostered. In addition, despite some promising preliminary results, varietal tolerance/resistance has, to date, received little attention. Finally, holistic decision-support tools for the implementation of IPM should be rendered available to farmers. Eventually, precise and verifiable targets for IPM implementation for each crop $\times$ wireworm species in the various cultivated areas [7] should be identified, with any relevant socio-economic aspects also being considered. 
Author Contributions: Conceptualization, S.P., R.L.C., J.L., M.P. and L.F.; writing一original draft preparation, S.P., R.L.C., J.L., M.P. and L.F.; writing-review and editing, S.P., R.L.C., J.L., M.P. and L.F.; project administration, S.P. All authors have read and agreed to the published version of the manuscript.

Funding: This research was supported by the French Office for Biodiversity (STARTAUP project); the "Groupement National Interprofessionnel des Semences et plants" (TAUPIN LAND project); and the French Ministry for Agriculture and Food for funding the TAUPIC project (CASDAR $\mathrm{n}^{\circ}$ 20ART1568739). The APC was funded by the Institute for Genetics, Environment and Plant Protection (IGEPP).

Institutional Review Board Statement: Not applicable.

Informed Consent Statement: Not applicable.

Acknowledgments: S.P., R.L.C. and M.P. acknowledge the French Office for Biodiversity for funding the STARTAUP project ("Design of alternative strategies for controlling wireworm damage in maize crops"); the "Groupement National Interprofessionnel des Semences et plants" (GNIS) for funding the TAUPIN LAND project; and the French Ministry for Agriculture and Food for funding the TAUPIC project (CASDAR n²0ART1568739). S.P. thanks Julien Saguez (CEROM, Quebec, Canada) for providing useful information about the web application VFF-QC and Leyli Borner (INRAE) for her assistance in producing Figure 1. R.L.C. and S.P. are grateful to Philippe Larroudé (Arvalis) and Jean-Claude Ogier (INRAE) for providing photographs.

Conflicts of Interest: The authors declare no conflict of interest.

\section{References}

1. Hallmann, C.A.; Sorg, M.; Jongejans, E.; Siepel, H.; Hofland, N.; Schwan, H.; Stenmans, W.; Müller, A.; Sumser, H.; Hörren, T.; et al. More than 75 Percent Decline over 27 Years in Total Flying Insect Biomass in Protected Areas. PLoS ONE 2017, 12, e0185809. [CrossRef] [PubMed]

2. Seibold, S.; Gossner, M.M.; Simons, N.K.; Blüthgen, N.; Müller, J.; Ambarlı, D.; Ammer, C.; Bauhus, J.; Fischer, M.; Habel, J.C.; et al. Arthropod Decline in Grasslands and Forests Is Associated with Landscape-Level Drivers. Nature 2019, 574, 671-674. [CrossRef] [PubMed]

3. Vogel, G. Where Have All the Insects Gone? Science 2017, 356, 576-579. [CrossRef] [PubMed]

4. Pisa, L.; Goulson, D.; Yang, E.-C.; Gibbons, D.; Sánchez-Bayo, F.; Mitchell, E.; Aebi, A.; van der Sluijs, J.; MacQuarrie, C.J.K.; Giorio, C.; et al. An Update of the Worldwide Integrated Assessment (WIA) on Systemic Insecticides. Part 2: Impacts on Organisms and Ecosystems. Environ. Sci. Pollut. Res. 2017. [CrossRef]

5. Labrie, G.; Gagnon, A.-Ė.; Vanasse, A.; Latraverse, A.; Tremblay, G. Impacts of Neonicotinoid Seed Treatments on Soil-Dwelling Pest Populations and Agronomic Parameters in Corn and Soybean in Quebec (Canada). PLoS ONE 2020, 15, e0229136. [CrossRef]

6. Balachowsky, A.; Mesnil, L. Les taupins. In Les Insectes Nuisibles aux Plantes Cultivées; Balachowsky, A., Ed.; Presses éts Busson: Paris, France, 1935; pp. 754-787.

7. Veres, A.; Wyckhuys, K.A.G.; Kiss, J.; Tóth, F.; Burgio, G.; Pons, X.; Avilla, C.; Vidal, S.; Razinger, J.; Bazok, R.; et al. An Update of the Worldwide Integrated Assessment (WIA) on Systemic Pesticides. Part 4: Alternatives in Major Cropping Systems. Environ. Sci. Pollut. Res. 2020. [CrossRef]

8. Furlan, L. An IPM Approach Targeted against Wireworms: What Has Been Done and What Has to Be Done. IOBC/WPRS Bull. 2005, 28, 91-100.

9. Furlan, L. The Biology of Agriotes Ustulatus Schaller (Col., Elateridae). II. Larval Development, Pupation, Whole Cycle Description and Practical Implications. J. Appl. Entomol. 1998, 122, 71-78. [CrossRef]

10. Furlan, L. The Biology of Agriotes Sordidus Illiger (Col., Elateridae). J. Appl. Entomol. 2004, 128, 696-706. [CrossRef]

11. Miles, H.W. Wireworms and Agriculture, with Special Reference to Agriotes Obscurus L. Ann. Appl. Biol. 1942, $29,176-180$. [CrossRef]

12. Sufyan, M.; Neuhoff, D.; Furlan, L. Larval Development of Agriotes Obscurus under Laboratory and Semi-Natural Conditions. Bull. Insectol. 2014, 67, 227-235.

13. Lehmhus, J.; Niepold, F. Identification of Agriotes Wireworms-Are They Always What They Appear to Be? J. Cultiv. Plants 2015, 67, 129-138.

14. Zacharuk, R.Y. Seasonal Behavior of Larvae of Ctenicera Spp. and Other Wireworms (Coleoptera:Elateridae), in Relation to Temperature, Moisture, Food, and Gravity. Can. J. Zool. 1962, 40, 697-718. [CrossRef]

15. Barzman, M.; Bàrberi, P.; Birch, A.N.E.; Boonekamp, P.; Dachbrodt-Saaydeh, S.; Graf, B.; Hommel, B.; Jensen, J.E.; Kiss, J.; Kudsk, P.; et al. Eight Principles of Integrated Pest Management. Agron. Sustain. Dev. 2015, 35, 1199-1215. [CrossRef]

16. Campbell, R.E. Temperature and Moisture Preferences of Wireworms. Ecology 1937, 18, 479-489. [CrossRef] 
17. Lafrance, J. The Seasonal Movements of Wireworms (Coleoptera: Elateridae) in Relation to Soil Moisture and Temperature in the Organic Soils of Southwestern Quebec. Can. Entomol. 1968, 100, 801-807. [CrossRef]

18. Kovacs, T.; Kuroli, G.; Pomsar, P.; Német, L.; Pali, O.; Kuroli, M. Localisation and Seasonal Positions of Wireworms in Soils. Commun. Agric. Appl. Biol. Sci. 2006, 71, 357-367.

19. Evans, A.C.; Gough, H.C. Observations on Some Factors Influencing Growth in Wireworms of the Genus Agriotes Esch. Ann. Appl. Biol. 1942, 29, 168-175. [CrossRef]

20. Furlan, L. The Biology of Agriotes Ustulatus Schäller (Col., Elateridae). I. Adults and Oviposition. J. Appl. Entomol. 1996, 120, 269-274. [CrossRef]

21. Jung, J.; Racca, P.; Schmitt, J.; Kleinhenz, B. SIMAGRIO-W: Development of a Prediction Model for Wireworms in Relation to Soil Moisture, Temperature and Type. J. Appl. Entomol. 2014, 138, 183-194. [CrossRef]

22. Lefko, S.A.; Pedigo, L.P.; Batchelor, W.D.; Rice, M.E. Spatial Modeling of Preferred Wireworm (Coleoptera: Elateridae) Habitat. Environ. Entomol. 1998, 27, 184-190. [CrossRef]

23. Furlan, L.; Contiero, B.; Chiarini, F.; Colauzzi, M.; Sartori, E.; Benvegnù, I.; Fracasso, F.; Giandon, P. Risk Assessment of Maize Damage by Wireworms (Coleoptera: Elateridae) as the First Step in Implementing IPM and in Reducing the Environmental Impact of Soil Insecticides. Environ. Sci. Pollut. Res. 2017, 24, 236-251. [CrossRef]

24. Kozina, A.; Lemic, D.; Bazok, R.; Mikac, K.M.; Mclean, C.M.; Ivezić, M.; Igrc Barčić, J. Climatic, Edaphic Factors and Cropping History Help Predict Click Beetle (Coleoptera: Elateridae) (Agriotes Spp.) Abundance. J. Insect Sci. 2015, 15, 100. [CrossRef]

25. Poggi, S.; Le Cointe, R.; Riou, J.-B.; Larroudé, P.; Thibord, J.-B.; Plantegenest, M. Relative Influence of Climate and Agroenvironmental Factors on Wireworm Damage Risk in Maize Crops. J. Pest. Sci. 2018, 91, 585-599. [CrossRef]

26. Blackshaw, R.P.; Vernon, R.S. Spatial Relationships between Two Agriotes Click-Beetle Species and Wireworms in Agricultural Fields. Agric. For. Entomol. 2008, 10, 1-11. [CrossRef]

27. Rawlins, R. Biology and Control of the Wheat Wireworm, Agriotes Mancus Say. Cornell Univ. Agric. Exp. Stn. Bull. 1940, 783, $1-34$.

28. Blackshaw, R.P.; Hicks, H. Distribution of Adult Stages of Soil Insect Pests across an Agricultural Landscape. J. Pest. Sci. 2013, 86, 53-62. [CrossRef]

29. Blackshaw, R.P.; Vernon, R.S. Spatiotemporal Stability of Two Beetle Populations in Non-Farmed Habitats in an Agricultural Landscape: Agriotes Distribution in an Agricultural Landscape. J. Appl. Ecol. 2006, 43, 680-689. [CrossRef]

30. Salt, G.; Hollick, F.S.J. Studies of Wireworm Populations: II. Spatial Distribution. J. Exp. Biol. 1946, 23, 1-46. [CrossRef]

31. Parker, W.E.; Seeney, F.M. An Investigation into the Use of Multiple Site Characteristics to Predict the Presence and Infestation Level of Wireworms (Agriotes Sup., Coleoptera: Elateridae) in Individual Grass Fields. Ann. Appl. Biol. 1997, 130, 409-425. [CrossRef]

32. Parker, W.E.; Howard, J.J. The Biology and Management of Wireworms (Agriotes Spp.) on Potato with Particular Reference to the U.K. Agric. For. Entomol. 2001, 3, 85-98. [CrossRef]

33. Blackshaw, R.P.; Vernon, R.S.; Thiebaud, F. Large Scale Agriotes Spp. Click Beetle (Coleoptera: Elateridae) Invasion of Crop Land from Field Margin Reservoirs: Click Beetle Dispersal. Agric. For. Entomol. 2017. [CrossRef]

34. Poggi, S.; Sergent, M.; Mammeri, Y.; Plantegenest, M.; Le Cointe, R.; Bourhis, Y. Dynamic Role of Grasslands as Sources of Soil-Dwelling Insect Pests: New Insights from in Silico Experiments for Pest Management Strategies. Ecol. Model. 2021, 440, 109378. [CrossRef]

35. Furlan, L. IPM Thresholds for Agriotes Wireworm Species in Maize in Southern Europe. J. Pest. Sci. 2014, 87. [CrossRef]

36. Esser, A.D.; Milosavljević, I.; Crowder, D.W. Effects of Neonicotinoids and Crop Rotation for Managing Wireworms in Wheat Crops. J. Econ. Entomol. 2015, 108, 1786-1794. [CrossRef]

37. Rambousek, F. Über Die Felddrahtwürmer. I. Systematischer Teil. Z. Zuckerind. Cechoslov. Repub. 1928, 52, $393-402$.

38. Schaerffenberg, B. Bestimmungsschlüssel der landwirtschaftlich wichtigsten Drahtwürmer. Anz. Für Schädlingskunde 1940, 16, 90-96. [CrossRef]

39. Pic, M.; Pierre, E.; Martinez, M.; Genson, G.; Rasplus, J.-Y.; Albert, H. Wireworms of genus Agriotes uncovered from their genetic prints. In Proceedings of the 9th Conférence Internationale sur les Ravageurs en Agriculture, Montpellier, France, 22 October 2008.

40. Staudacher, K.; Pitterl, P.; Furlan, L.; Cate, P.C.; Traugott, M. PCR-Based Species Identification of Agriotes Larvae. Bull. Entomol. Res. 2011, 101, 201-210. [CrossRef]

41. Heimbach, U.; Lehmhus, J.; Zamani-Noor, N. Clarification of Efficacy Data Requirements for the Authorization of an Insecticideapplied as Seed Treatment for the Control of Wireworms Incrops Such Asmaize, Sunflowers, Millet and Sugar Beet in the EU; European and Mediterranean Plant Protection Organization (EPPO): Paris, France, 2020.

42. Lehmhus, J. Wireworm Biology in Middle Europe-What Are We Facing? Microbial and Nematode Control of Invertebrate Pests. IOBC-WPRS Bull. 2020, 150, 96-99.

43. Eidt, D.C. A Description of the Larva of Agriotes Mancus (Say), with a Key Separating the Larvae of A. Lineatus (L.), A. Mancus, A. Obscurus (L.), and A. Sputator (L.) from Nova Scotia. Can. Entomol 1954, 86, 481-494. [CrossRef]

44. Benefer, C.M.; van Herk, W.G.; Ellis, J.S.; Blackshaw, R.P.; Vernon, R.S.; Knight, M.E. The Molecular Identification and Genetic Diversity of Economically Important Wireworm Species (Coleoptera: Elateridae) in Canada. J. Pest. Sci. 2013, 86, 19-27. [CrossRef] 
45. Glen, R.; King, K.M.; Arnason, A.P. The Identification of Wireworms of Economic Importance in Canada. Can. J. Res. 1943, 21d, 358-387. [CrossRef]

46. Riley, T.J.; Keaster, A.J. Wireworms Associated with Corn: Identification of Larvae of Nine Species of Melanotus1 from the North Central States2. Ann. Entomol. Soc. Am. 1979, 72, 408-414. [CrossRef]

47. Etzler, F.E.; Wanner, K.W.; Morales-Rodriguez, A.; Ivie, M.A. DNA Barcoding to Improve the Species-Level Management of Wireworms (Coleoptera: Elateridae). J. Econ. Entomol 2014, 107, 1476-1485. [CrossRef]

48. Oba, Y.; Ôhira, H.; Murase, Y.; Moriyama, A.; Kumazawa, Y. DNA Barcoding of Japanese Click Beetles (Coleoptera, Elateridae). PLOS ONE 2015, 10, e0116612. [CrossRef]

49. Zhang, S.; Liu, Y.; Shu, J.; Zhang, W.; Zhang, Y.; Wang, H. DNA Barcoding Identification and Genetic Diversity of Bamboo Shoot Wireworms (Coleoptera: Elateridae) in South China. J. Asia Pac. Entomol. 2019, 22, 140-150. [CrossRef]

50. Milosavljević, I.; Esser, A.D.; Crowder, D.W. Seasonal Population Dynamics of Wireworms in Wheat Crops in the Pacific Northwestern United States. J. Pest. Sci. 2017, 90, 77-86. [CrossRef]

51. Staudacher, K.; Schallhart, N.; Pitterl, P.; Wallinger, C.; Brunner, N.; Landl, M.; Kromp, B.; Glauninger, J.; Traugott, M. Occurrence of Agriotes Wireworms in Austrian Agricultural Land. J. Pest. Sci. 2013, 86, 33-39. [CrossRef]

52. Saussure, S.; Plantegenest, M.; Thibord, J.-B.; Larroudé, P.; Poggi, S. Management of Wireworm Damage in Maize Fields Using New, Landscape-Scale Strategies. Agron. Sustain. Dev. 2015, 35, 793-802. [CrossRef]

53. Milosavljević, I.; Esser, A.D.; Crowder, D.W. Effects of Environmental and Agronomic Factors on Soil-Dwelling Pest Communities in Cereal Crops. Agric. Ecosyst. Environ. 2016, 225, 192-198. [CrossRef]

54. Seal, D.R.; Chalfant, R.B.; Hall, M.R. Effects of Cultural Practices and Rotational Crops on Abundance of Wireworms (Coleoptera: Elateridae) Affecting Sweet potato in Georgia. Environ. Entomol. 1992, 21, 969-974. [CrossRef]

55. Salt, G.; Hollick, F.S.J. Studies of Wireworm Population: III. Some Effects of Cultivation. Ann. Appl. Biol. 1949, 36, 169-186. [CrossRef]

56. Hermann, A.; Brunner, N.; Hann, P.; Wrbka, T.; Kromp, B. Correlations between Wireworm Damages in Potato Fields and Landscape Structure at Different Scales. J. Pest. Sci. 2013, 86, 41-51. [CrossRef]

57. Furlan, L.; Contiero, B.; Chiarini, F.; Benvegnù, I.; Tóth, M. The Use of Click Beetle Pheromone Traps to Optimize the Risk Assessment of Wireworm (Coleoptera: Elateridae) Maize Damage. Sci. Rep. 2020, 10, 8780. [CrossRef]

58. Furlan, L.; Vasileiadis, V.P.; Chiarini, F.; Huiting, H.; Leskovšek, R.; Razinger, J.; Holb, I.J.; Sartori, E.; Urek, G.; Verschwele, A.; et al. Risk Assessment of Soil-Pest Damage to Grain Maize in Europe within the Framework of Integrated Pest Management. Crop. Prot. 2017, 97, 52-59. [CrossRef]

59. Saguez, J.; Latraverse, A.; De Almeida, J.; van Herk, W.G.; Vernon, R.S.; Légaré, J.-P.; Moisan-De Serres, J.; Fréchette, M.; Labrie, G. Wireworm in Quebec Field Crops: Specific Community Composition in North America. Environ. Entomol. 2017, 46, 814-825. [CrossRef]

60. Butler, L.I.; McDonough, L.M.; Onsager, J.A.; Landis, B.J. Sex Pheromones of the Pacific Coast Wireworm, Limonius Canus 12. Environ. Entomol. 1975, 4, 229-230. [CrossRef]

61. Jacobson, M.; Lilly, C.E.; Harding, C. Sex Attractant of Sugar Beet Wireworm: Identification and Biological Activity. Science 1968, 159, 208-210. [CrossRef]

62. Yatsynin, V.G.; Rubanova, E.V.; Okhrimenko, N.V. Identification of Female-Produced Sex Pheromones and Their Geographical Differences in Pheromone Gland Extract Composition from Click Beetles (Col., Elateridae). J. Appl. Entomol. 1996, 120, 463-466. [CrossRef]

63. Borg-Karlson, A.-K.; Ågren, L.; Dobson, H.; Bergström, G. Identification and Electroantennographic Activity of Sex-Specific Geranyl Esters in an Abdominal Gland of FemaleAgriotes Obscurus (L.) AndA. Lineatus (L.) (Coleoptera, Elateridae). Experientia 1988, 44, 531-534. [CrossRef]

64. Tóth, M.; Furlan, L.; Yatsynin, V.G.; Ujváry, I.; Szarukán, I.; Imrei, Z.; Tolasch, T.; Francke, W.; Jossi, W. Identification of Pheromones and Optimization of Bait Composition for Click Beetle Pests (Coleoptera: Elateridae) in Central and Western Europe: Pheromones and Optimization of Bait Composition for Click Beetles. Pest. Manag. Sci. 2003, 59, 417-425. [CrossRef]

65. Burgio, G.; Ragaglini, G.; Petacchi, R.; Ferrari, R.; Pozzati, M.; Furlan, L. Optimization of Agriotes Sordidus Monitoring in Northern Italy Rural Landscape, Using a Spatial Approach. Bull. Insectol. 2012, 65, 123-131.

66. Vernon, R.S. A Ground-Based Pheromone Trap for Monitoring Agriotes Lineatus and A. Obscurus (Coleoptera: Elateridae). J. Entomol. Soc. Br. Columbia 2004, 101, 141-142.

67. Witzgall, P.; Kirsch, P.; Cork, A. Sex Pheromones and Their Impact on Pest Management. J. Chem. Ecol. 2010, 36, 80-100. [CrossRef] [PubMed]

68. Blackshaw, R.P.; van Herk, W.G.; Vernon, R.S. Determination of Agriotes Obscurus (Coleoptera: Elateridae) Sex Pheromone Attraction Range Using Target Male Behavioural Responses: Pheromone Attraction Range of Agriotes Obscurus. Agr For. Entomol. 2018, 20, 228-233. [CrossRef]

69. Sufyan, M.; Neuhoff, D.; Furlan, L. Assessment of the Range of Attraction of Pheromone Traps to Agriotes Lineatus and Agriotes Obscurus. Agric. For. Entomol. 2011, 13, 313-319. [CrossRef]

70. Hicks, H.; Blackshaw, R.P. Differential Responses of Three Agriotes Click Beetle Species to Pheromone Traps. Agric. For. Entomol. 2008, 10, 443-448. [CrossRef] 
71. Kishita, M.; Arakaki, N.; Kawamura, F.; Sadoyama, Y.; Yamamura, K. Estimation of Population Density and Dispersal Parameters of the Adult Sugarcane Wireworm, Melanotus Okinawensis Ohira (Coleoptera: Elateridae), on Ikei Island, Okinawa, by MarkRecapture Experiments. Appl. Entomol. Zool. 2003, 38, 233-240. [CrossRef]

72. Benefer, C.M.; Knight, M.E.; Ellis, J.S.; Hicks, H.; Blackshaw, R.P. Understanding the Relationship between Adult and Larval Agriotes Distributions: The Effect of Sampling Method, Species Identification and Abiotic Variables. Appl. Soil Ecol. 2012, 53, 39-48. [CrossRef]

73. Reddy, G.V.P.; Tangtrakulwanich, K. Potential Application of Pheromones in Monitoring, Mating Disruption, and Control of Click Beetles (Coleoptera: Elateridae). ISRN Entomol. 2014, 2014, 1-8. [CrossRef]

74. Doane, J.F.; Lee, Y.W.; Klingler, J.; Westcott, N.D. The Orientation Response of Ctemcera Destructor and Other Wireworms (Coleoptera: Elateridae) to Germinating Grain and to Carbon Dioxide. Can. Entomol 1975, 107, 1233-1252. [CrossRef]

75. Doane, J.F.; Klingler, J. Location of Co2-Receptive Sensilla on Larvae of the Wireworms Agriotes Lineatus-Obscurus and Limonius Californicus1. Ann. Entomol. Soc. Am. 1978, 71, 357-363. [CrossRef]

76. Parker, W.E. Evaluation of the Use of Food Baits for Detecting Wireworms (Agriotes Spp., Coleoptera: Elateridae) in Fields Intended for Arable Crop Production. Crop. Prot. 1994, 13, 271-276. [CrossRef]

77. Brunner, N.; Grünbacher, E.M.; Kromp, B. Comparison of Three Different Bait Trap Types for Wireworms (Coleoptera: Elateridae) in Arable Crops. IOBS/WPRS Bull. 2007, 30, 47-52.

78. Morales-Rodriguez, A.; Ospina, A.; Wanner, K.W. Evaluation of Four Bait Traps for Sampling Wireworm (Coleoptera: Elateridae) Infesting Cereal Crops in Montana. Int. J. Insect Sci. 2017, 9, 1-11. [CrossRef]

79. Landl, M.; Furlan, L.; Glauninger, J. Seasonal Fluctuations in Agriotes Spp. (Coleoptera: Elateridae) at Two Sites in Austria and the Efficiency of Bait Trap Designs for Monitoring Wireworm Populations in the Soil. J. Plant. Dis. Prot. 2010, 117, $268-272$. [CrossRef]

80. Chabert, A.; Blot, Y. Estimation Des Populations Larvaires de Taupins Par Un Piège Attractif. Phytoma 1992, 436, 26-30.

81. Kirfman, G.W.; Keaster, A.J.; Story, R.N. An Improved Wireworm (Coleoptera: Elateridae) Sampling Technique for Midwest Cornfields. J. Kans. Entomol Soc. 1986, 59, 37-41.

82. Cherry, R.; Grose, P.; Barbieri, E. Validation of a Sequential Sampling Plan for Wireworms (Coleoptera: Elateridae) at Sugarcane Planting. J. Pest. Sci. 2013, 86, 29-32. [CrossRef]

83. Griffiths, D.C. Susceptibility of Plants to Attack by Wireworms (Agriotes Spp.). Ann. Appl. Biol. 1974, 78, 7-13. [CrossRef]

84. Milosavljević, I.; Esser, A.D.; Murphy, K.M.; Crowder, D.W. Effects of Imidacloprid Seed Treatments on Crop Yields and Economic Returns of Cereal Crops. Crop. Prot. 2019, 119, 166-171. [CrossRef]

85. Furlan, L.; Bonetto, C.; Finotto, A.; Lazzeri, L.; Malaguti, L.; Patalano, G.; Parker, W. The Efficacy of Biofumigant Meals and Plants to Control Wireworm Populations. Ind. Crop. Prod. 2010, 31, 245-254. [CrossRef]

86. Furlan, L.; Bonetto, C.; Costa, B.; Finotto, A.; Lazzeri, L. Observations on Natural Mortality Factors in Wireworm Populations and Evaluation of Management Options. IOBC/WPRS Bull. 2009, 45, 436-439.

87. Lees, A.D. On the Behaviour of Wireworms of the Genus Agriotes Esch. (Coleoptera, Elateridae). J. Exp. Biol. 1943, 20, 54-60. [CrossRef]

88. Landis, B.J.; Onsager, J.A. Wireworms on Irrigated Lands in the West: How to Control Them. In Farmer's Bulletin; U.S. Department of Agriculture: Washington, DC, USA, 1966.

89. Shirck, F.H. Crop Rotations and Cultural Practices as Related to Wireworm Control in Idaho12. J. Econ. Entomol. 1945, 38, 627-633. [CrossRef]

90. Hall, D.G.; Cherry, R.H. Effect of Temperature in Flooding to Control the Wireworm Melanotus Communis (Coleoptera: Elateridae). Fla. Entomol. 1993, 76, 155. [CrossRef]

91. Van Herk, W.G.; Vernon, R.S. Effect of Temperature and Soil on the Control of a Wireworm, Agriotes Obscurus L. (Coleoptera: Elateridae) by Flooding. Crop. Prot. 2006, 25, 1057-1061. [CrossRef]

92. Onsager, J.A.; Foiles, L.L. Chemical Control of the Great Basin Wireworm on Potatoes. J. Econ. Entomol. 1969, 62, 1506-1507. [CrossRef]

93. Andrews, N.; Ambrosino, M.; Fisher, G.; Rondon, S.I. Wireworm Biology and Nonchemical Management in Potatoes in the Pacific Northwest; A Pacific Northwest Extension Publication, Oregon State University: Corvallis, OR, USA, 2008.

94. Samoylova, E.S.; Tiunov, A.V. Flexible Trophic Position of Polyphagous Wireworms (Coleoptera, Elateridae): A Stable Isotope Study in the Steppe Belt of Russia. Appl. Soil Ecol. 2017, 121, 74-81. [CrossRef]

95. Lane, M.C.; Jones, E.W. Flooding As A Means of Reducing Wireworm Infestations. J. Econ. Entomol. 1936, 29, 842-850. [CrossRef]

96. Genung, W.G. Flooding Experiments for Control of Wireworms Attacking Vegetable Crops in the Everglades. Fla. Entomol. 1970, 53, 55. [CrossRef]

97. Arakaki, N.; Nagayama, A.; Kobayashi, A.; Kishita, M.; Sadoyama, Y.; Mougi, N.; Kawamura, F.; Wakamura, S.; Yamamura, K. Control of the Sugarcane Click Beetle Melanotus Okinawensis Ohira (Coleoptera: Elateridae) by Mass Trapping Using Synthetic Sex Pheromone on Ikei Island, Okinawa, Japan. Appl. Entomol. Zool. 2008, 43, 37-47. [CrossRef]

98. Arakaki, N.; Nagayama, A.; Kobayashi, A.; Tarora, K.; Kishita, M.; Sadoyama, Y.; Mougi, N.; Kijima, K.; Suzuki, Y.; Akino, T.; et al. Estimation of Abundance and Dispersal Distance of the Sugarcane Click Beetle Melanotus Sakishimensis Ohira (Coleoptera: Elateridae) on Kurima Island, Okinawa, by Mark-Recapture Experiments. Appl. Entomol. Zool. 2008, 43, 409-419. [CrossRef] 
99. Sufyan, M.; Neuhoff, D.; Furlan, L. Effect of Male Mass Trapping of Agriotes Species on Wireworm Abundance and Potato Tuber Damage. Bull. Insectol. 2013, 66, 135-142.

100. Vernon, R.S.; Blackshaw, R.P.; van Herk, W.G.; Clodius, M. Mass Trapping Wild Agriotes Obscurus and Agriotes Lineatus Males with Pheromone Traps in a Permanent Grassland Population Reservoir: Pheromone Trapping of Agriotes Beetles. Agr For. Entomol. 2014, 16, 227-239. [CrossRef]

101. Ritter, C.; Richter, E. Control Methods and Monitoring of Agriotes Wireworms (Coleoptera: Elateridae). J. Plant. Dis. Prot. 2013, 120, 4-15. [CrossRef]

102. Van Herk, W.G.; Vernon, R.S. Local Depletion of Click Beetle Populations by Pheromone Traps Is Weather and Species Dependent. Environ. Entomol. 2020, 49, 449-460. [CrossRef]

103. Van Lenteren, J.C.; Bolckmans, K.; Köhl, J.; Ravensberg, W.J.; Urbaneja, A. Biological Control Using Invertebrates and Microorganisms: Plenty of New Opportunities. BioControl 2018, 63, 39-59. [CrossRef]

104. Kleespies, R.G.; Ritter, C.; Zimmermann, G.; Burghause, F.; Feiertag, S.; Leclerque, A. A Survey of Microbial Antagonists of Agriotes Wireworms from Germany and Italy. J. Pest. Sci 2013, 86, 99-106. [CrossRef]

105. Hyslop, J.A. Wireworms Attacking Cereal and Forage Crops; U.S. Dept. of Agriculture: Washington, DC, USA, 1915.

106. Subklew, W. Die Bekämpfung Der Elateriden: Eine Übersicht Über Die Literatur. Z. Für Angew. Entomol. 1938, $24,511-581$. [CrossRef]

107. Kirk, D.A.; Evenden, M.D.; Mineau, P. Past and Current Attempts to Evaluate the Role of Birds as Predators of Insect Pests in Temperate Agriculture. In Current Ornithology; Nolan, V., Ketterson, E.D., Eds.; Springer: Boston, MA, USA, 1996; pp. 175-269. ISBN 978-1-4613-7697-2.

108. Fox, C.J.S.; MacLellan, C.R. Some Carabidae and Staphylinidae Shown to Feed on a Wireworm, Agriotes Sputator (L.), by the Precipitin Test. Can. Entomol 1956, 88, 228-231. [CrossRef]

109. Van Herk, W.G.; Vernon, R.S.; Cronin, E.M.L.; Gaimari, S.D. Predation of Thereva Nobilitata (Fabricius) (Diptera: Therevidae) on Agriotes Obscurus L. (Coleoptera: Elateridae). J. Appl. Entomol. 2015, 139, 154-157. [CrossRef]

110. Rabb, R.L. Biology of Conoderus Vespertinus in the Piedmont Section of North Carolina (Coleoptera: Elateridae). Ann. Entomol. Soc. Am. 1963, 56, 669-676. [CrossRef]

111. Rizzo, C.; Lehmhus, J. Wireworm Food Choice: Steack or Salad? Jul. Kühn Arch. 2014, 447, 543-544.

112. Traugott, M.; Schallhart, N.; Kaufmann, R.; Juen, A. The Feeding Ecology of Elaterid Larvae in Central European Arable Land: New Perspectives Based on Naturally Occurring Stable Isotopes. Soil Biol. Biochem. 2008, 40, 342-349. [CrossRef]

113. D’Aguilar, J. Sur Paracodrus Apterogynus Hal. (Hym. Proctotrupidae), Parasite Des Larves d'Agriotes En France. Bull. Soc. Entomol. Fr. 1948, 53, 154-155.

114. Langenbuch, R. Beiträge Zur Kenntnis Der Biologie von Agriotes Lineatus L. Und Agriotes Obscurus L. Z. Für Angew. Entomol. 1932, 19, 278-300. [CrossRef]

115. Leclerque, A.; Kleespies, R.G.; Ritter, C.; Schuster, C.; Feiertag, S. Genetic and Electron-Microscopic Characterization of 'Rickettsiella Agriotidis', a New Rickettsiella Pathotype Associated with Wireworm, Agriotes Sp. (Coleoptera: Elateridae). Curr. Microbiol. 2011, 63, 158-163. [CrossRef]

116. Danismazoglu, M.; Demir, İ.; Sevim, A.; Demirbag, Z.; Nalcacioglu, R. An Investigation on the Bacterial Flora of Agriotes Lineatus (Coleoptera: Elateridae) and Pathogenicity of the Flora Members. Crop. Prot. 2012, 40, 1-7. [CrossRef]

117. Subklew, W. Agriotes Lineatus L. Und Agriotes Obscurus L: (Ein Beitrag Zu Ihrer Morphologie Und Biologie.). Z. Für Angezw. Entomol. 1935, 21, 96-122. [CrossRef]

118. Zolk, K. Paracodrus Apterogynus Halid. Kui tumeda viljanaksuri (Agriotes Obscurus L.) toukude uus parasiit. Tartu Ülikooli Entomoloogia Katsejaama Teadaanded 1924, 3, 10.

119. Blunck, H. Parasiten Der Elateridenlarven. Z. Für Angew. Entomol. 1925, 11, 148-149. [CrossRef]

120. Nixon, G.E.J. A Preliminary Revision of the British Proctotrupinae (Hym., Proctotrupoidea). Trans. R. Entomol. Soc. Lond. 1938, 87, 431-465. [CrossRef]

121. Bognar, S. Pristocera Depressa a Paralysing and Destructive Parasite of the Wireworm, A. Obscurus. Novenytermeles 1955, 4 , 241-252.

122. Kabaluk, J.T.; Goettel, M.; Erlandson, M.; Ericsson, J.; Duke, G.M.; Vernon, R.S. Metarhizium Anisopliae as a Biological Control for Wireworms and a Report of Some Other Naturally-Occurring Parasites. IOBC/WPRS Bull. 2005, 28, $109-115$.

123. Nickle, W.R. A Contribution to Our Knowledge of the Mermithidae (Nematoda). J. Nematol. 1972, 4, 113-146.

124. Platzer, E.G. Biological Control of Mosquitoes with Mermithids. J. Nematol. 1981, 13, 257-262. [PubMed]

125. Doane, J.F.; Klingler, J.; Welch, H.E. Parasitism of Agriotes Obscurus Linnaeus (Coleoptera: Elateridae) by Hexamermis Sp. (Nematoda: Mermithidae. B. Soc. Entomol. Suisse 1973, 45, 299-300.

126. Stock, S.P.; Blair, H.G. Entomopathogenic Nematodes and Their Bacterial Symbionts: The inside out of a Mutualistic Association. Symbiosis 2008, 46, 65-75.

127. Campos-Herrera, R.; Gutiérrez, C. Screening Spanish Isolates of Steinernematid Nematodes for Use as Biological Control Agents through Laboratory and Greenhouse Microcosm Studies. J. Invertebr. Pathol. 2009, 100, 100-105. [CrossRef]

128. Eidt, D.C.; Thurston, G.S. Physical Deterrents to Infection by Entomopathogenic Nematodes in Wireworms (Coleoptera: Elateridae) and Other Soil Insects. Can. Entomol. 1995, 127, 423-429. [CrossRef] 
129. Toba, H.H.; Lindegren, J.E.; Turner, J.E.; Vail, P.V. Susceptibility of the Colorado Potato Beetle and the Sugarbeet Wireworm to Steinernema Feltiae and S. Glaseri. J. Nematol. 1983, 15, 597-601.

130. Schalk, J.M.; Bohac, J.R.; Dukes, P.D.; Martin, W.R. Potential of Non-Chemical Control Strategies for Reduction of Soil Insect Damage in Sweetpotato. JASHS 1993, 118, 605-608. [CrossRef]

131. Kovacs, A.; Deseo, K.V.; Poinar, J.G.O.; De Leoardis, A. Prove Di Lotta Contro Insetti Con Applicazione Di Nematode Entomogeni. ATTI G Fitopatol. 1980, 1, 499-546.

132. Ansari, M.A.; Evans, M.; Butt, T.M. Identification of Pathogenic Strains of Entomopathogenic Nematodes and Fungi for Wireworm Control. Crop. Prot. 2009, 28, 269-272. [CrossRef]

133. Ester, A.; Huiting, H. Controlling Wireworms (Agriotes Spp.) in a Potato Crop with Biologicals. IOBC/WPRS Bull. 2007, 30, 189-196.

134. Rahatkhah, Z.; Karimi, J.; Ghadamyari, M.; Brivio, M.F. Immune Defenses of Agriotes Lineatus Larvae against Entomopathogenic Nematodes. BioControl 2015, 60, 641-653. [CrossRef]

135. Morton, A.; Garcia-del-Pino, F. Laboratory and Field Evaluation of Entomopathogenic Nematodes for Control of Agriotes Obscurus (L.) (Coleoptera: Elateridae). J. Appl. Entomol. 2017, 141, 241-246. [CrossRef]

136. Turian, G. Entomophthora Elateridiphaga n.Sp. Sur Imagos d'Agriotes Sputator L. Bull. Soc. Entomol. Suisse 1978, 51, $395-398$.

137. Keller, S. The Fungus Zoophthora Elateridiphaga as an Important Mortality Factor of the Click Beetle Agriotes Sputator. J. Invertebr. Pathol. 1994, 63, 90-91. [CrossRef]

138. Dara, S.K.; Humber, R.A. Entomophthoran. In Beneficial Microbes in Agro-Ecology; Elsevier: Amsterdam, The Netherlands, 2020; pp. 757-775. ISBN 978-0-12-823414-3.

139. Keller, S. Zoophthora Elateridiphaga (Zygomycetes, Entomophthoraceae) Causing Epizootics in Populations of Notostira Elongata (Heteroptera, Miridae). Bull. Soc. Entomol. Suisse 1982, 55, 289-296.

140. McCoy, C.W. Entomogenous Fungi as Microbial Pesticides. In Proceedings of the New Directions in Biological Control. Alternatives for Suppressing Agricultural Pests and Diseases; Baker, R.R., Dunn, P.E., Eds.; Wiley: New York, NY, USA, 1990.

141. Zacharuk, R.Y. Penetration of the Cuticular Layers of Elaterid Larvae (Coleoptera) by the Fungus Metarrhizium Anisopliae, and Notes on a Bacterial Invasion. J. Invertebr. Pathol. 1973, 21, 101-106. [CrossRef]

142. Leger, R.J.S.; Goettel, M.; Roberts, D.W.; Staples, R.C. Prepenetration Events during Infection of Host Cuticle by Metarhizium Anisopliae. J. Invertebr. Pathol. 1991, 58, 168-179. [CrossRef]

143. Ladurner, E.; Quentin, U.; Franceschini, S.; Benuzzi, M. Efficacy Evaluation of the Entomopathogenic Fungus Beauveria Bassiana Strain ATCC 74040 against Wireworms (Agriotes Spp.) on Potato. IOBC/WPRS Bull. 2009, 45, 445-448.

144. Schepl, U.; Paffrath, A.; Kempkens, K. Regulierungskonzepte Zur Reduktion von Drahtwurmschäden; Landwirtschaftskammer Nordrhein-Westfalen: Münster, Germany, 2010; 55p.

145. Kölliker-Ott, U.; Biasio, L.; Jossi, W. Potential Control of Swiss Wireworms with Entomopathogenic Fungi. IOBC/WPRS BULL. 2011, 66, 517-520.

146. Eckard, S.; Ansari, M.A.; Bacher, S.; Butt, T.M.; Enkerli, J.; Grabenweger, G. Virulence of in Vivo and in Vitro Produced Conidia of Metarhizium Brunneum Strains for Control of Wireworms. Crop. Prot. 2014, 64, 137-142. [CrossRef]

147. Zacharuk, R.Y.; Tinline, R.D. Pathogenicity of Metarrhizium Anisopliae, and Other Fungi, for Five Elaterids (Coleoptera) in Saskatchewan. J. Invertebr. Pathol. 1968, 12, 294-309. [CrossRef]

148. Kabaluk, T.; Li-Leger, E.; Nam, S. Metarhizium Brunneum-An Enzootic Wireworm Disease and Evidence for Its Suppression by Bacterial Symbionts. J. Invertebr. Pathol. 2017, 150, 82-87. [CrossRef]

149. Gillespie, A.T.; Claydon, N. The Use of Entomogenous Fungi for Pest Control and the Role of Toxins in Pathogenesis. Pestic. Sci. 1989, 27, 203-215. [CrossRef]

150. Rogge, S.A.; Mayerhofer, J.; Enkerli, J.; Bacher, S.; Grabenweger, G. Preventive Application of an Entomopathogenic Fungus in Cover Crops for Wireworm Control. BioControl 2017, 62, 613-623. [CrossRef]

151. Kabaluk, J.T.; Ericsson, J.D. Environmental and Behavioral Constraints on the Infection of Wireworms by Metarhizium Anisopliae. Environ. Entomol. 2007, 36, 1415-1420. [CrossRef]

152. Brian, M.V. On the Ecology of Beetles of the Genus Agriotes with Special Reference to A. Obscurus. J. Anim. Ecol. 1947, 16, 210. [CrossRef]

153. Burrage, R.H. Seasonal Feeding of Larvae of Ctenicera Destructor and Hypolithus Bicolor (Coleoptera: Elateridae) on Potatoes Placed in the Field at Weekly Intervals. Ann. Entomol. Soc. Am. 1963, 56, 306-313. [CrossRef]

154. Sonnemann, I.; Grunz, S.; Wurst, S. Horizontal Migration of Click Beetle (Agriotes Spp.) Larvae Depends on Food Availability. Entomol. Exp. Appl. 2014, 150, 174-178. [CrossRef]

155. Staley, J.T.; Hodgson, C.J.; Mortimer, S.R.; Morecroft, M.D.; Masters, G.J.; Brown, V.K.; Taylor, M.E. Effects of Summer Rainfall Manipulations on the Abundance and Vertical Distribution of Herbivorous Soil Macro-Invertebrates. Eur. J. Soil Biol. 2007, 43, 189-198. [CrossRef]

156. Vänninen, I. Distribution and Occurrence of Four Entomopathogenic Fungi in Finland: Effect of Geographical Location, Habitat Type and Soil Type. Mycol. Res. 1996, 100, 93-101. [CrossRef]

157. Rohde, C.; Moino, A., Jr.; da Silva, M.A.T.; Carvalho, F.D.; Ferreira, C.S. Influence of Soil Temperature and Moisture on the Infectivity of Entomopathogenic Nematodes (Rhabditida: Heterorhabditidae, Steinernematidae) against Larvae of Ceratitis Capitata (Wiedemann) (Diptera: Tephritidae). Neotrop. Entomol. 2010, 39, 608-611. [CrossRef] [PubMed] 
158. El Khoury, Y.; Oreste, M.; Noujeim, E.; Nemer, N.; Tarasco, E. Effect of Temperature on the Pathogenecity of Mediterranean Native Entomopathogenic Nematodes (Steinernematidae and Heterorhabditidae) from Natural Ecosystems. Redia 2018, $123-127$. [CrossRef]

159. Ensafi, P.; Crowder, D.W.; Esser, A.D.; Zhao, Z.; Marshall, J.M.; Rashed, A. Soil Type Mediates the Effectiveness of Biological Control Against Limonius Californicus (Coleoptera: Elateridae). J. Econ. Entomol. 2018, 111, 2053-2058. [CrossRef]

160. El-Borai, F.E.; Stuart, R.J.; Campos-Herrera, R.; Pathak, E.; Duncan, L.W. Entomopathogenic Nematodes, Root Weevil Larvae, and Dynamic Interactions among Soil Texture, Plant Growth, Herbivory, and Predation. J. Invertebr. Pathol. 2012, 109, 134-142. [CrossRef]

161. Toledo, J.; Williams, T.; Pérez, C.; Liedo, P.; Valle, J.F.; Ibarra, J.E. Abiotic Factors Affecting the Infectivity of Steinernema Carpocapsae (Rhabditida: Steinernematidae) on Larvae of Anastrepha Obliqua (Diptera: Tephritidae). Biocontrol. Sci. Technol. 2009, 19, 887-898. [CrossRef]

162. Toepfer, S.; Kurtz, B.; Kuhlmann, U. Influence of Soil on the Efficacy of Entomopathogenic Nematodes in Reducing Diabrotica Virgifera Virgifera in Maize. J. Pest. Sci. 2010, 83, 257-264. [CrossRef]

163. Ericsson, J.D.; Kabaluk, J.T.; Goettel, M.S.; Myers, J.H. Spinosad Interacts Synergistically with the Insect Pathogen Metarhizium Anisopliae Against the Exotic Wireworms Agriotes Lineatus and Agriotes Obscurus (Coleoptera: Elateridae). J. Econ. Entomol. 2007, 100, 31-38. [CrossRef]

164. Glare, T.R. Stage-dependent Synergism Using Metarhizium Anisopliae and Serratia Entomophila against Costelytra Zealandica. Biocontrol. Sci. Technol. 1994, 4, 321-329. [CrossRef]

165. Ansari, M.A.; Shah, F.A.; Butt, T.M. Combined Use of Entomopathogenic Nematodes and Metarhizium Anisopliae as a New Approach for Black Vine Weevil, Otiorhynchus Sulcatus, Control. Entomol. Exp. Appl. 2008, 129, 340-347. [CrossRef]

166. Dlamini, B.E.; Malan, A.P.; Addison, P. Combined Effect of Entomopathogenic Fungi and Steinernema Yirgalemense against the Banded Fruit Weevil, Phlyctinus Callosus (Coleoptera: Curculionidae). Biocontrol. Sci. Technol. 2020, 30, 1169-1179. [CrossRef]

167. Usman, M.; Gulzar, S.; Wakil, W.; Wu, S.; Piñero, J.C.; Leskey, T.C.; Nixon, L.J.; Oliveira-Hofman, C.; Toews, M.D.; Shapiro-Ilan, D. Virulence of Entomopathogenic Fungi to Rhagoletis Pomonella (Diptera: Tephritidae) and Interactions With Entomopathogenic Nematodes. J. Econ. Entomol. 2020, 113, 2627-2633. [CrossRef]

168. Jaronski, S.T. Ecological Factors in the Inundative Use of Fungal Entomopathogens. BioControl 2010, 55, 159-185. [CrossRef]

169. Jaronski, S.T.; Jackson, M.A. Efficacy of Metarhizium Anisopliae Microsclerotial Granules. Biocontrol Sci. Technol. 2008, 18, 849-863. [CrossRef]

170. Reddy, G.V.P.; Tangtrakulwanich, K.; Wu, S.; Miller, J.H.; Ophus, V.L.; Prewett, J.; Jaronski, S.T. Evaluation of the Effectiveness of Entomopathogens for the Management of Wireworms (Coleoptera: Elateridae) on Spring Wheat. J. Invertebr. Pathol. 2014, 120, 43-49. [CrossRef]

171. Küppers, R.; Neuhoff, D.; Stumm, C. Einfluss Des Biologischen Insektizids ATTRACAP®Auf Den Drahtwurmbefall von Speisekartoffeln. In Leitbetriebe Ökologischer Landbau Nordrhein-Westfalen; Agrarökologie \& Organischer Landbau, Universität Bonn: Bonn, Germany, 2017; pp. 114-128.

172. Brandl, M.A.; Schumann, M.; Przyklenk, M.; Patel, A.; Vidal, S. Wireworm Damage Reduction in Potatoes with an Attract-and-Kill Strategy Using Metarhizium Brunneum. J. Pest. Sci. 2017, 90, 479-493. [CrossRef]

173. Toba, H.H.; Pike, K.S.; O'Keeffe, F.E. Carbosulfan, Fonofos, and Lindane Wheat Seed Treatments for Control of Sugarbeet Wireworm. J. Agric. Entomol. 1988, 5, 35-43.

174. Kuhar, T.P.; Alvarez, J.M. Timing of Injury and Efficacy of Soil-Applied Insecticides against Wireworms on Potato in Virginia. Crop. Prot. 2008, 27, 792-798. [CrossRef]

175. Vernon, R.S.; Van Herk, W.; Tolman, J.; Ortiz Saavedra, H.; Clodius, M.; Gage, B. Transitional Sublethal and Lethal Effects of Insecticides after Dermal Exposures to Five Economic Species of Wireworms (Coleoptera: Elateridae). J. Econ. Entomol. 2008, 101, 365-374. [CrossRef] [PubMed]

176. Klingler, J. Über Die Bedeutung Des Kohlendioxyds Für Die Orientierung Der Larven von Otiorrhynchus Sulcatus F., Melolontha Und Agriotes (Col.) Im Boden (Vorläufige Mitteilung). Bull. Soc. Entomol. Suisse 1957, 30, 317-322.

177. Schumann, M.; Patel, A.; Vidal, S. Soil Application of an Encapsulated $\mathrm{CO}_{2}$ Source and Its Potential for Management of Western Corn Rootworm Larvae. J. Econ. Entomol. 2014, 107, 230-239. [CrossRef]

178. Guerenstein, P.G.; Hildebrand, J.G. Roles and Effects of Environmental Carbon Dioxide in Insect Life. Ann. Rev. Entomol. 2008, 53, 161-178. [CrossRef]

179. Barsics, F.; Haubruge, E.; Francis, F.; Verheggen, F. The Role of Olfaction in Wireworms: A Review on Their Foraging Behavior and Sensory Apparatus. Biotechnol. Agron. Soc. Environ. 2014, 18, 524-535.

180. Barsics, F.; Delory, B.M.; Delaplace, P.; Francis, F.; Fauconnier, M.-L.; Haubruge, É.; Verheggen, F.J. Foraging Wireworms Are Attracted to Root-Produced Volatile Aldehydes. J. Pest. Sci 2017, 90, 69-76. [CrossRef]

181. Johnson, S.N.; Nielsen, U.N. Foraging in the Dark-Chemically Mediated Host Plant Location by Belowground Insect Herbivores. J. Chem. Ecol. 2012, 38, 604-614. [CrossRef]

182. La Forgia, D.; Jaffuel, G.; Campos-Herrera, R.; Verheggen, F.; Turlings, T. Efficiency of an Attract-and-Kill System with Entomopathogenic Nematodes against Wireworms (Coleoptera: Elateridae). IOBC/WPRS Bull. 2020, 150, 91-95.

183. Kabaluk, J.T.; Lafontaine, J.P.; Borden, J.H. An Attract and Kill Tactic for Click Beetles Based on Metarhizium Brunneum and a New Formulation of Sex Pheromone. J. Pest. Sci. 2015, 88, 707-716. [CrossRef] 
184. Vuts, J.; Furlan, L.; Csonka, É.B.; Woodcock, C.M.; Caulfield, J.C.; Mayon, P.; Pickett, J.A.; Birkett, M.A.; Tóth, M. Development of a Female Attractant for the Click Beetle Pest Agriotes Brevis: Plant Attractants for Female Click Beetles. Pest. Manag. Sci. 2014, 70, 610-614. [CrossRef]

185. Vuts, J.; Furlan, L.; Tóth, M. Female Responses to Synthetic Pheromone and Plant Compounds in Agriotes Brevis Candeze (Coleoptera: Elateridae). J. Insect Behav. 2018, 31, 106-117. [CrossRef]

186. Tóth, M.; Furlan, L.; Vuts, J.; Szarukán, I.; Ujváry, I.; Yatsynin, V.G.; Tolasch, T.; Francke, W. Geranyl Hexanoate, the FemaleProduced Pheromone of Agriotes Sordidus Illiger (Coleoptera: Elateridae) and Its Activity on Both Sexes. Chemoecology 2015, 25, 1-10. [CrossRef]

187. Tóth, M.; Furlan, L.; Szarukán, I.; Nagy, A.; Vuts, J.; Toshova, T.; Velchev, D.; Lohonyai, Z.; Imrei, Z. The Addition of a Pheromone to a Floral Lure Increases Catches of Females of the Click Beetle Agriotes Ustulatus (Schaller) (Coleoptera: Elateridae). J. Chem. Ecol. 2019, 45, 667-672. [CrossRef]

188. Doane, J.F. The Flat Wireworm, Aeolus Mellillus: Studies on Seasonal Occurrence of Adults and Incidence of the Larvae in the Wireworm Complex Attacking Wheat in Saskatchewan1. Environ. Entomol. 1977, 6, 818-820. [CrossRef]

189. Jansson, R.K.; Seal, D.R. Biology and Management of Wireworms on Potato. In Proceedings of the International Conference on 'Advances in Potato Pest Biology and Management', Jackson Hole, WY, USA, 12-17 October 1991; pp. 31-53.

190. Vernon, B.; Pats, P. Distribution of Two European Wireworms, Agriotes Lineatus and A. Obscurus in British Columbia. J. Entomol. Soc. Br. Columbia 1997, 94, 59-62.

191. Mahéo, F.; Lehmhus, J.; Larroudé, P.; Le Cointe, R. Un Outil Moléculaire Simple et Abordable Pour Identifier Les Larves de Taupins Du Genre Agriotes. Cah. Tech. Inra 2020, 102, 1-8.

192. Andrews, K.R.; Gerritsen, A.; Rashed, A.; Crowder, D.W.; Rondon, S.I.; van Herk, W.G.; Vernon, R.; Wanner, K.W.; Wilson, C.M.; New, D.D.; et al. Wireworm (Coleoptera: Elateridae) Genomic Analysis Reveals Putative Cryptic Species, Population Structure, and Adaptation to Pest Control. Commun. Biol. 2020, 3, 489. [CrossRef]

193. Klausnitzer, B. Familie Elateridae. In Die Larven der Käfer Mitteleuropas; Gustav Fischer: Jena, Germany, $1994 ;$ pp. $118-189$.

194. Martensen, A.C.; Saura, S.; Fortin, M.-J. Spatio-Temporal Connectivity: Assessing the Amount of Reachable Habitat in Dynamic Landscapes. Methods Ecol. Evol. 2017, 8, 1253-1264. [CrossRef]

195. Taylor, P.D.; Fahrig, L.; Henein, K.; Merriam, G. Connectivity Is a Vital Element of Landscape Structure. Oikos 1993, 68, 571. [CrossRef]

196. Jonsson, M.; Wratten, S.D.; Landis, D.A.; Tompkins, J.-M.L.; Cullen, R. Habitat Manipulation to Mitigate the Impacts of Invasive Arthropod Pests. Biol. Invasions 2010, 12, 2933-2945. [CrossRef]

197. Parisey, N.; Bourhis, Y.; Roques, L.; Soubeyrand, S.; Ricci, B.; Poggi, S. Rearranging Agricultural Landscapes towards Habitat Quality Optimisation: In Silico Application to Pest Regulation. Ecol. Complex. 2016, 113-122. [CrossRef]

198. Polasky, S.; Nelson, E.; Camm, J.; Csuti, B.; Fackler, P.; Lonsdorf, E.; Montgomery, C.; White, D.; Arthur, J.; Garber-Yonts, B.; et al. Where to Put Things? Spatial Land Management to Sustain Biodiversity and Economic Returns. Biol. Conserv. 2008, 141, 1505-1524. [CrossRef]

199. Jedlička, P.; Frouz, J. Population Dynamics of Wireworms (Coleoptera, Elateridae) in Arable Land after Abandonment. Biologia 2007, 62. [CrossRef]

200. Neuhoff, D.; Christen, C.; Paffrath, A.; Schepl, U. Approaches to Wireworm Control in Organic Potato Production. IOBC/WPRS Bull. 2007, 30, 65-68.

201. La Forgia, D.; Thibord, J.-B.; Larroudé, P.; Francis, F.; Lognay, G.; Verheggen, F. Linking Variety-Dependent Root Volatile Organic Compounds in Maize with Differential Infestation by Wireworms. J. Pest. Sci. 2020, 93, 605-614. [CrossRef]

202. Rawlins, W.A. Some Varietal Differences in Wireworm Injury to Potatoes. Am. Potato J. 1943, 20, 156-158. [CrossRef]

203. Parker, W.E.; Howard, J.J. Assessment of the Relative Susceptibility of Potato Cultivars to Damage by Wireworms (Agriotes Spp.). Tests Agrochem. Cultiv. 2000, 21, 15-16.

204. Langdon, K.W.; Abney, M.R. Relative Susceptibility of Selected Potato Cultivars to Feeding by Two Wireworm Species at Two Soil Moisture Levels. Crop. Prot. 2017, 101, 24-28. [CrossRef]

205. Kwon, M.; Hahm, Y.I.; Shin, K.Y.; Ahn, Y.J. Evaluation of Various Potato Cultivars for Resistance to Wireworms (Coleoptera: Elateridae). Am. J. Pot Res. 1999, 76, 317-319. [CrossRef]

206. Sonnemann, I.; Baumhaker, H.; Wurst, S. Species Specific Responses of Common Grassland Plants to a Generalist Root Herbivore (Agriotes Spp. Larvae). Basic Appl. Ecol. 2012, 13, 579-586. [CrossRef]

207. Johnson, S.N.; Gregory, P.J. Chemically-Mediated Host-Plant Location and Selection by Root-Feeding Insects. Physiol. Entomol. 2006, 31, 1-13. [CrossRef]

208. La Forgia, D.; Verheggen, F. The Law of Attraction: Identification of Volatiles Organic Compounds Emitted by Potatoes as Wireworms Attractant. Commun. Agric. Appl. Biol. Sci. 2017, 82, 167-169.

209. Thorpe, W.H.; Crombie, A.C.; Hill, R.; Darrah, J.H. The Behaviour of Wireworms in Response to Chemical Stimulation. J. Exp. Biol. 1947, 23, 234. [CrossRef]

210. Le Cointe, R.; Girault, Y.; Morvan, T.; Thibord, J.-B.; Larroudé, P.; Lecuyer, G.; Plantegenest, M.; Bouillé, D.; Poggi, S. Feeding Pests as an $\{\mathrm{IPM}\}$ Strategy: Wireworms in Conservation Agriculture as Case Study. In Proceedings of the 3rd Annual International Branch Virtual Symposium of the Entomological Society of America, 27-29 April 2020.

211. Hokkanen, H.M.T. Trap Cropping in Pest Management. Ann. Rev. Entomol. 1991, 36, 119-138. [CrossRef] 
212. Miles, H.W.; Petherbridge, F.R. Investigations on the Control of Wireworms. Ann. Appl. Biol. 1927, 14, 359-387. [CrossRef]

213. Vernon, R.S.; Kabaluk, T.; Behringer, A. Movement of Agriotes Obscurus (Coleoptera: Elateridae) in Strawberry (Rosaceae) Plantings with Wheat (Gramineae) as a Trap Crop. Can. Entomol. 2000, 132, 231-241. [CrossRef]

214. Landl, M.; Glauninger, J. Preliminary Investigations into the Use of Trap Crops to Control Agriotes Spp. (Coleoptera: Elateridae) in Potato Crops. J. Pest. Sci. 2013, 86, 85-90. [CrossRef]

215. Adhikari, A.; Reddy, G.V.P. Evaluation of Trap Crops for the Management of Wireworms in Spring Wheat in Montana. Arthropod Plant. Interact. 2017, 11, 755-766. [CrossRef]

216. Sharma, A.; Sandhi, R.K.; Briar, S.S.; Miller, J.H.; Reddy, G.V.P. Assessing the Performance of Pea and Lentil at Different Seeding Densities as Trap Crops for the Management of Wireworms in Spring Wheat. J. Appl. Entomol. 2019, 143, 460-469. [CrossRef]

217. Staudacher, K.; Schallhart, N.; Thalinger, B.; Wallinger, C.; Juen, A.; Traugott, M. Plant Diversity Affects Behavior of Generalist Root Herbivores, Reduces Crop Damage, and Enhances Crop Yield. Ecol. Appl. 2013, 23, 1135-1145. [CrossRef] [PubMed]

218. Thibord, J.-B.; Larroudé, P.; Tour, M.; Ogier, J.C.; Barsics, F. Le Dossier Taupins: Nouvelles Stratégies-Les Solutions à Venir s'inspirent de La Nature. Perspect. Agric. 2015, 427, 58-62.

219. Furlan, L.; Benvegnù, I.; Chiarini, F.; Loddo, D.; Morari, F. Meadow-Ploughing Timing as an Integrated Pest Management Tactic to Prevent Soil-Pest Damage to Maize. Eur. J. Agron. 2020, 112, 125950. [CrossRef]

220. Furlan, L.; Pozzebon, A.; Duso, C.; Simon-Delso, N.; Sánchez-Bayo, F.; Marchand, P.A.; Codato, F.; Bijleveld van Lexmond, M.; Bonmatin, J.-M. An Update of the Worldwide Integrated Assessment (WIA) on Systemic Insecticides. Part 3: Alternatives to Systemic Insecticides. Environ. Sci. Pollut. Res. 2018. [CrossRef] 